\title{
ATEBE
}

Dinî Araștırmalar Dergisi

Journal for Religious Studies

ATEBE Dergisi / Journal of ATEBE

e-ISSN: 2757-5616| Haziran / June 2021/1, 5: 35-57

\section{Osmanlı Kıbrıs'ında Gayrimüslim ve Kilise Vakıfları}

\author{
Non-Muslim and Church Waqfs in the Ottoman Cyprus
}

\begin{abstract}
Siddık Korkmazer
Doktora Öğrencisi, Bursa Uludağ Üniversitesi, Sosyal Bilimler Enstitüsü, İslam Tarihi Anabilim Dalı PhD Student, Bursa Uludağ University, Institute of Social Sciences, Department of Islamic History

\author{
Bursa/Turkey \\ skorkmazer@hotmail.com \\ orcid.org/ 0000-0002-3967-2002
}

\begin{abstract}
Makale Bilgisi / Article Information
Makale Türü / Article Types: Araştırma Makalesi / Research Article
\end{abstract}

Geliş Tarihi / Date Received: 6 Nisan/April 2021

Kabul Tarihi / Date Accepted: 29 Mayıs/May 2021

Yayın Tarihi / Date Published: 15 Haziran/June 2021

Yayın Sezonu / Pub Date Season: Haziran/June

Atıf / Cite as: Korkmazer, Sıddık. “Osmanlı Kıbrıs'ında Gayrimüslim ve Kilise Vakıfları = Non-Muslim and Church Waqfs in The Ottoman Cyprus". ATEBE 5 (Haziran 2021), 35-57. https://doi.org/10.51575/atebe.910572

İntihal / Plagiarism: Bu makale, iTenticate yazılımınca taranmıştır. İntihal tespit edilmemiştir/This article has been scanned by iTenticate. No plagiarism detected.

Etik Beyan/Ethical Statement: Bu çalışmanın hazırlanma sürecinde bilimsel ve etik ilkelere uyulduğu ve yararlanılan tüm çalışmaların kaynakçada belirtildiği beyan olunur/It is declared that scientific and ethical principles have been followed while carrying out and writing this study and that all the sources used have been properly cited (Sıddık Korkmazer).

Copyright (C) Published by Ankara Sosyal Bilimler Üniversitesi, İslami İlimler Fakültesi / Social Sciences University of Ankara, Faculty of Islamic Sciences, Ankara, 06050 Turkey. All rights reserved.

CC BY-NC-ND 4.0 | This paper is licensed under a Creative Commons Attribution-NonCommercial NoDerivatives International License.

CC BY-NC-ND 4.0 | This paper is licensed under a Creative Commons Attribution-NonCommercial NoDerivatives International License. 


\title{
Osmanlı Kıbrıs'ında Gayrimüslim ve Kilise Vakıfları*
}

Öz

Geçmişi insanlık tarihi kadar eski olan iyilik yapma ve sevap kazanma duygusundan doğan vakıf, İslam ile birlikte hukuksal bir zemin kazanarak ebedi bir müessese haline gelmiştir. Sosyo-kültürel ve dini hizmetleri üstlenen vakıf ya da vakfa benzer fiiller yalnızca Müslümanlar arasında değil diğer dinlere mensup insanlar arasında da yaygın şekilde görülmekteydi. Örneğin Hint devletlerinde kralların din adamı olan Brahmanlara köyler hediye ettiği görülmektedir. Brahmanlar bu köylerin mülküne sahip olmamakta, köylüler tarafından işlenen toprakların gelirini almakta ve böylece varidat sahibi olmaktaydılar. Dârülislâm'da gerek Müslüman gerekse de gayrimüslim tebaa tarafından kurulan vakıflar şerî hukuka bağlı olarak faaliyet göstermekteydi. Osmanlı Devleti'nin üç yüz yedi yıl hüküm sürdüğü Kıbrıs Adası'nda da aynı şerî hükümler bağlamında çok sayıda vakfın kurulduğu görülmektedir. Osmanlı Dönemi Kıbrıs vakıfları üzerine birçok çalışma yapılmasına rağmen bunlardan yalnızca biri gayrimüslim vakıflarını konu edinmektedir. Söz konusu çalışmada ise yalnızca yedi şahıs vakfı ele alınmakta ancak kiliselere ait fetih öncesi ve sonrası vakıflarına değinilmemektedir. Bu çalışmada işaret edilen söz konusu eksiklik üzerinde durulacaktır. Genel olarak KKTC Girne Milli Arşiv ve Araştırma Dairesinde bulunan Kıbrıs Şer'iyye Sicilleri kaynak olarak alınmakla birlikte, Osmanlı Arşivi ve Vakıflar Genel Müdürlüğü Arşivinden tespit edilen belgeler analiz edilecektir. Öncelikle gayrimüslim ve zimmî kavramları açıklanarak Kıbrıs'ta bu kategoriye giren şahıslar ve bunların hukuki haklarına değinilip İslam hukukunda gayrimüslimlerin vakıf kurma hakları üzerinde durulacaktır. Diğer bir başlık altında iki tablo halinde verilen biri iptal edilmiş on bir şahıs vakfı ile farklı cemaatlere ait yirmi bir kilise ve manastır vakfı ayrıntılı olarak incelenecektir.

Anahtar Kelimeler: İslam Tarihi, Kıbrıs, Vakıflar, Gayrimüslimler, Kilise Vakıfları.

\section{Non-Muslim and Church Waqfs in The Ottoman Cyprus}

\begin{abstract}
Having emerged out of the notions of doing good and gaining good deeds, the institution of waqf, which is as old as the history of humanity, gained a legal basis with Islam and became a perpetual institution. The institution of waqf which is concerned with undertaking socio-cultural and religious services, or similar acts, were common not only among Muslims but also among people belonging to other religions. For example, it is known that Indian kings donated villages to Brahmans who were clergymen. While the Brahmans did not own the property of these villages, they received the income of the lands cultivated by the peasants, and thus had revenues. The waqf institutions established by both Muslim and non-Muslim subjects in Dar al-Islam operated under the Shari'ah law. It is known that many institutions of waqf were established in the context of the same Shari'ah provisions in Cyprus, where the Ottoman Empire ruled for three hundred and seven years. Although there have been many studies on the institutions of waqf in Ottoman Cyprus, only one of them deals with non-Muslim foundations. That study goes into only seven private foundations, while not mentioning pre and post-conquest institutions of waqf belonging to churches. This present study aims to contribute to this gap in the literature. It is based on the analysis of the Cyprus Shar'iyyah records in the Turkish Republic of Northern Cyprus as the main source of the study, in addition to the documents from the Ottoman archive and the Archives of the Directorate General of Foundations. First, by explaining the concepts of non-Muslim and dhimmī, it will address the individuals in this category in Cyprus and their legal rights, and will focus on the rights of non-Muslims to establish foundations according to the Islamic law. It will examine in detail eleven private foundations, one of which was abolished, in addition to twenty-one church and monastery foundations belonging to different congregations.
\end{abstract}

Keywords: Islamic History, Cyprus, Waqfs, Non-Muslim, Church Waqfs.

* Bu çalışma devam etmekte olan “Osmanlı Dönemi Kıbrıs Vakıfları (1571-1826)” başlıklı doktora tezi (Bursa Uludağ Üniversitesi, Bursa) esas alınarak hazırlanmıştır. / This article is prepared on the basis of doctoral dissertation titled “Cyprus Waqfs in Ottoman Rule (1571-1826)” PhD Dissertation, (Bursa Uludağ University, Bursa/Turkey). 


\section{Extended Abstract}

Having emerged out of the notions of doing good and gaining good deeds, the institution of al-waqf(foundation), which is as old as the history of humanity, gained a legal basis with Islam and became a perpetual institution. Concerned with undertaking socio-cultural and religious services or similar acts, the institution of waqf was common not only among Muslims but also among people who were part of other religious beliefs. For example, it is seen that kings in the Indian countries donated villages to the Brahmins, who were clergymen. Brahmans did not own the property of these villages. They only took the income of the lands cultivated by the peasants and thus had revenues. The waqfs, established by both -Muslim and non-Muslim subjects- in Dâr al-Islâm, operated under Sharî'ah law. It is seen that many waqfs were established in the context of the same Sharî'ah provisions in Cyprus, where the Ottoman Empire ruled for three hundred and seven years.

In the research we made on the registers of Cyprus Shar'iyyah, we found out the records of 11 non-Muslim waqfs, 21 church waqfs, and one waqf was shut down because of not fulfilling the legal requirements. One of these nonMuslim waqfs was founded by Jews, two by Armenians, and eight by Rums (Greeks). Meanwhile, 13 of the Church waqfs belong to Greek Orthodox, the other two to Armenian, four to the Archbishop of Tûr-i Sînâ, and two to the Greek Patriarchate of Jerusalem. The only non-Muslim waqf was founded by the Jews, and the mevkûf's (the donated property's) conditions' stipulated that while it could be used for the benefit of the Jewish community, its income needed to be used for the benefit of another religious community. All of the other waqfs were presented to benefit the poor or religious officials of the religion to which the wâqif (founder) is a member, and the trustee's members of the waqf were required to be trustees of the churches as well. It is seen that the nonMuslims who had the same rights and responsibilities as Muslims in establishing charitable waqfs had had their foundations shut down when they did not fulfill one or more of these conditions. Based on the archive records, we can see that there were Catholic and Orthodox churches and properties belonging to these churches before the Ottoman Empire took the island of Cyprus. Especially in some of the Registers of Important Affairs (Muhimme Defterleri) covering the conquest of Cyprus and the following period, besides many Catholic churches turned in mosques or sold as properties, there are many records about the Tûr-i Sînâ Monastery and some other churches and waqfs continuing their work actively. After the conquest of Cyprus, the most important Cathedrals and churches belonging to the Catholics, especially those in Nicosia and Famagusta, whose church activities on the island were terminated due to their harbî (war) status, were converted into mosques together with their properties and waqfs. Besides this, the Ottoman Empire provided religious, social, and political rights and financial opportunities to the both Orthodox and Armenian communities, as they helped Ottomans in the war.

While some of the churches and monasteries belonging to Catholics were given to Orthodox Greeks and Armenians, some of them were sold together with the waqfs and properties they owned, and the income obtained by selling them was recorded in the state treasury. Looking at the Christian waqfs in Cyprus, it is seen that the creator of the waqf has generally stipulated that the trustee of the foundation has to be either the priest of the poorer of the church or the trustee of the church (as a waqf). Only in one waqf founded by Mario binti Yanni, a non-Muslim named Hiristoğlu son of Konomidi, is mentioned as a trustee. Trusteeship will be transferred to that authority or to the person that will take the post only when the duty or life of the trustee ends. When the mevkûfs are examined, it is seen that ten waqfs have endowed the real estates. Within the site of different mevkûfs that are part of 8 different waqfs, there are different numbers of rooms, gardens, trees, etc. In addition to the ten ranges that host it, one garden with trees and irrigation rights have been given.

\section{Giriș}

İnsanların sevap kazanma amacıyla tercih ettikleri iyilik yapma yöntemlerinden biri olan vakıf; Müslüman, Hristiyan ve Yahudi bireyler arasında yaygın bir uygulamadır. ${ }^{1}$ Arapça, durdurmak, alıkoymak, hapsetmek manalarına gelen vakıf kelimesi fikhî terim olarak âkıl bâliğ, hür bir kişinin sahibi olduğu bir mülkü, menfaati diğer insan ve canlılara ait olmak üzere temlik ve temellükten çıkartarak Allah'ın mülkü haline getirmesi demektir.2

İslam'dan önceki medeniyetlerde ictimaî ve dinî saiklerle insanların yararına bağışlanmıș kuyu, köprü, ev, çeşme vb. vakıf fiili mevcut olmasına rağmen İslam'da olduğu gibi hukuksal bir

1 Diğer dinlerdeki vakıf uygulamaları için bk. Ahmed Akgündüz, İslam Hukukunda ve İslam Tatbikatında Vakıf Müessesesi (İstanbul: Osmanlı Araştırmaları Vakfı, 1996), 48-55; Walter Ruben, "Budhist Vakıfları Hakkında", Vakıflar Dergisi 2 (1942), 173-184; Mehmed Fuad Köprülü, İslam ve Türk Hukuk Tarihi Araştırmaları ve Vakıf Müessesesi (Ankara: Akçağ Yayınları, 2005), 299-307.

2 Ömer Hilmi Efendi, Ahkâmü'l-evkaf (İstanbul: Matbâ-i Âmire, 1307), 2; Hacı Mehmet Günay, “Vakıf”, Türkiye Diyanet Vakfi İslam Ansiklopedisi (İstanbul: TDV Yayınları, 2012), 42/475. 
zemin ve ebedî bir müessese meydana getirilememiștir. ${ }^{3}$ Müslümanlar Kur'ân-ı Kerîm ${ }^{4}$ ve sünnetten ${ }^{5}$ hareketle vakıf kurmaya önem vermişlerdir. Sadece sevap kazanmak amacıyla değil gerek sahip oldukları mülkleri korumak gerekse de istediği kişiye mirasından pay ayırmak için çok sayıda vakıf kurulmuştur. İslam devletlerinde Müslümanların yanında gayrimüslimler tarafından da İslam hukukunun kendilerine izin verdiği çerçevede çok sayıda vakıf kurulmuştur. ${ }^{6}$ Bu makalede ise Hz. Osman'dan itibaren İslam coğrafyasının bir parçası haline gelen Kıbrıs'ta, Osmanlı Devleti döneminde kurulan gayrimüslim vakıfları incelenmiștir.

Spesifik olarak Kıbrıs'taki gayrimüslim vakıflarını konu edinen tek çalışma Soyalp Tamçelik ve M. Kemal Kasapoğlu tarafından kaleme alınan "Kıbrıs'ta Kurulan Gayrımüslim Vakıfları ve Özellikleri” isimli çalışmadır. Mezkûr çalışmada Kıbrıs'ta kurulmuş yalnızca 7 gayrimüslim vakfı üzerinde durulmuştur. Ada'da bulunan kiliselere ait Osmanlı öncesi var olup Osmanlı döneminde devam eden vakıflara değinilmemiştir. ${ }^{7}$ Nitekim Kıbrıs Şer'iyye sicilleri üzerinde yaptığımız araștırmada aynı döneme ait biri hukuki şartları yerine getirmediği için iptal edilmiş on bir gayrimüslim vakfı yanında mütevellileri tarafından idare edilen yirmi bir tane kilise vakıf kaydı bulunmaktadır. Bu makalede yukarıda zikredilen belgeler bağlamında literatüre katkı sağlanmaya çalışılmıştır.

Gayrimüslimler tarafından kurulan vakıflara ve vakıf kurma şartlarına geçmeden önce gayrimüslim denilince kimlerin kastedildiği açıklanmalıdır. İslam hukukunun geçerli olduğu diğer devletlerde olduğu gibi Osmanlı'da da insanlar ırklarına göre değil mensubu oldukları inanca göre sınıflandırılmaktaydılar. Üzerinde bütün mezheplerce ittifak sağlanmamakla beraber genel olarak Dârülislâm'da Müslümanlar dışında kalan Hristiyan, Yahudi ve Mecûsîlere gayrimüslim denilmektedir. Bunlardan ülke vatandaşı olanlara zimmî, ülkede belirli bir süre ikamet edenlere de müste'men denilmektedir. ${ }^{8}$ Bunlar Müslümanların çoğunluğu gibi devlete vergi verip devletten can, mal güvenliği yanında sosyo-kültürel ve dinî haklarının sürdürülmesi yönünde hizmet gördükleri için devlete vergi veren Müslümanlar ile birlikte reâyâ olarak tanımlanmaktadırlar. ${ }^{9}$ Kıbrıs'ta da gayrimüslim reâyâ; Ortodoks Rumlar, Ermeniler, Yahudiler, Suriyeli Ya'kûbîler ve Sînâ Hristiyanlarından oluşmaktayd.. ${ }^{10}$

Osmanlı, Kıbrıs adasını fethettiğinde savaştı̆̆ı millet olan Katolik Venedikliler/Latinler harbî gruptan sayılmış, bütün mülkleri ile kiliselerine de el konulmuş ve reâyâ kısmına dahil edilmemişlerdir. Venediklilerde yönetici ve hâkim konuma mensup olan Katoliklerin çoğu, savaşta ya öldürüldüler ya da esir edildiler. Antlaşmalarla Ada'dan ayrılanların dışında geriye kalanları ise Ortodoksluk ya da Müslümanlık arasında tercihte bulundular. Nitekim George

3 Vakıfların menșei ve tarihte ortaya çıkıșı hakkındaki tartışmalar için bk. Ali Himmet Berki, "Vakıfların Hukuk, Mahiyeti, İnkişafı ve Tekâmülü, Cemiyet ve Fertlere Sağladığı Faideler”, Vakıflar Dergisi 6 (1965), 9-10; Köprülü, İslam ve Türk Hukuk Tarihi Araştırmaları ve Vakıf Müessesesi, 295-343; Nazif Öztürk, Menşei ve Tarihi Gelişimi Açısından Vakıflar (Ankara: Vakıflar Genel Müdürlüğ̈̈, 1983), 30-40.

4 Vakıf kurumunu teşvik eden etmenler için bk. Kur'ân-ı Kerîm, Bakara/ 83, Nisa/ 36, Tevbe/ 58, 60.

5 "İnsan ölünce bütün amelleri kesilir. Ancak şu üç şeyde kesilmeyip devam eder: Sadaka-i câriye, faydalanılan ilim, öldükten sonra kendisine dua eden hayırlı bir evlat” Müslim b. el-Haccac, Sahihi Müslim, ed. Muhammed Fuad Abdülbaki (Beyrut: Dâru İhyai't-Türaasi'l Arabi, 1956), “Vasiyye”, 14.

6 Osmanlı döneminde gayrimüslimlerin vakıf kurma hakları ve bu hakkın fiiliyattaki durumu için bk: Eugenia Kermeli, "Ebû's-Su'ûd'a Göre Kilise Vakıfları Osmanlı Hukukundaki Teori ve Pratiği", çev. Özcan Özgen, Vakıflar Dergisi 34 (2010), 165-176; Belkıs Konan, "Gayrimüslim Osmanlı Vatandaşlarının Hukuki Durumuna İlişskin Bir Değerlendirme”, Ankara Üniversitesi Hukuk Fakültesi Dergisi 64/1 (01 Mart 2015), 171-194; Muhammed Ceyhan, Osmanlı Devleti'nde Gayrimüslimlerin Mülk ve Vakıf Edinimi (18. yüzyıl), Ankara: Ankara Üniversitesi, Sosyal Bilimler Enstitüsü, Doktora Tezi, 2016; Soyalp Tamçelik - Mustafa Kemal Kasapoğlu, "Kıbrıs'ta Kurulan Gayrımüslim Vakıfları ve Özellikleri (Non-Muslim Foundations Constituted in Cyprus and Their Characteristics)", Osmanlı Dönemi Kıbrıs Vakıfları (Lefkoşa: Yakın Doğu Üniversitesi Yayınları, 2017), 279-338; Kenan Yıldız, "Aykırı Vakıflar: Osmanlıda Fukarâ-yı Müslimîni de Gözeten Gayrimüslim Vakıfları”, Osmanlı Araştırmaları 54 (21 Haziran 2019), 141-198.

7 Tamçelik-Kasapoğlu, "Kıbrıs'ta Kurulan Gayrımüslim Vakıfları ve Özellikleri (Non-Muslim Foundations Constituted in Cyprus And Their Characteristics)".

8 Ahmet Özel, "Gayrimüslim", Türkiye Diyanet Vakfi İslam Ansiklopedisi (İstanbul: TDV Yayınları, 1996); Akgündüz, Íslam Hukukunda ve İslam Tatbikatında Vakıf Müessesesi, 238.

9 Muhammed Hamidullah, Íslam'da Devlet İdaresi, çev. Kemal Kuşcu (İstanbul: Beyan Yayınları, 1998), 133136; Mehmet Öz, "Reâyâ", Türkiye Diyanet Vakfı İslam Ansiklopedisi (İstanbul: TDV Yayınları, 2007), 34/490.

10 Mustafa Şengil, Osmanlı'dan Günümüze Kıbrıs İnanç Tarihi (Konya: Necmettin Erbakan Üniversitesi Sosyal Bilimler Enstitüsü, Doktora, 2020), 33-65. 
Hill'in iddiasına göre bu kişiler bundan sonra Ortodoks ayinlerine katılmış, Katolik kiliseleri de ya çürümeye terkedilmiş ya da başka amaçlar için kullanılmıştır.11

Fethin tamamlanmasından sonra ada üzerindeki devlet düzeninin kurulması sırasında bizzat padişah II. Selim tarafından beylerbeyi, kadı ve defterdara hitaben yazılan 23 Zilhicce 979/7 Mayıs 1572 tarihli fermanda, Ada'nın yeni fethedildiği, yeniden imar ve ihya edilirken reâyânın kendisine Allah'ın bir emaneti olduklarını unutmadan mîrî hizmetler, kiralama ve vergi toplamada adalet üzere hareket etmeleri, toplum arasında tefrika çıkaracak hareketlerden uzak durulması ve reâyânın güvenlik ve mutluluğu için gerekli hassasiyetin gösterilmesi konusunda ehemmiyetle durulmuş aksi durumda hiçbir mazeretin geçerli olmayacağı özellikle vurgulanmıştır. ${ }^{12}$

Kıbrıs'taki gayrimüslim reâyâyı genel olarak üç grupta toplamak mümkündür. Bunların en üst kademesinde Venedik döneminde hakları gasp edilmiş Ortodoks kilisesine ait Başpiskoposlar, papazlar, Ada Rumlarını temsilen Lefkoşa Divanında bulunan Divan Tercümanları ve Avrupalı ülkelerin konsolosluklarında görevli Dragomanlar bulunmaktadır. Gayrimüslim reâyânın oluşturduğu diğer iki grup ise zimmî esnaf ve tüccarlar ile köylülerdir. ${ }^{13}$ Mezhepler arası çekişmelerden dolayı Katolik Venedikliler tarafından büyük baskılara maruz kalan Ortodoks Rumlar ve Ermeniler Osmanlı döneminde hakları iade edilerek kiliseleri özerk bir yapı kazanmıștır. Kiliseleri, bu dönemden sonra cemaatlerinin temsilcisi konumuna gelmiştir. ${ }^{14}$ Başpiskoposlar padişahtan aldıkları beratlarla Rumlar ve Ermeniler tarafından seçilmiştir. Hükümet adına gayrimüslim kesimden vergi toplama yetkisi de verildiğinden büyük güç ve nüfuza sahip olan kilise, belli dönemlerde devletin başına sorunlar da çıkarmıştır. ${ }^{15}$ Gayrimüslim reâyâ askerlik gibi mecburi görevlerden muaf tutulduğundan ticaretle meşgul olmuşlar ve nitekim özellikle köylülerin ürettikleri ürünleri satarak ve Müslümanlara yasak olan faizle para kazanma yolu olan tefecilik yaparak zengin bir Rum ve Ermeni esnafı ortaya çıkarmışlardır. Müslüman köylülerden farklı olmayan gayrimüslim köylüler de cizye ve haraç denilen vergiler dışında Müslümanlar gibi bağ, bahçe vergisi vererek toprak sahibi olabilmekte ve mülklerini miras olarak bırakabilmekteydiler. ${ }^{16}$

\section{Kıbrıs'ta Zimmîlerin Vakıf Kurma Hakları}

İnsanların vakıf kurma niyetleri farklı farklı olsa bile İslam hukukuna göre hizmetleri bakımından vakıflar ikiye ayrılmaktadır. Bunlardan hedefi aile bireylerine hizmet olanlarına zürrî/ehlî vakıf, amacı aile bireyleri dışındaki kişilere hayır yapmak olanlara ise hayrî vakıf denilmektedir. Bunun yanında her iki grubun yararına kurulan vakıflar da yarı ailevî/ yarı hayrî vakıf olarak isimlendirilmiştir. ${ }^{17}$ İslam hukuku bakımından ailevî/ zürrî vakıflar belli gruplar elinde mülk gibi korunmaya devam ettiğinden fukahâ nezdinde tartışmalıdır. Ancak Osmanlı ulemâsı bu konuda Hanefî imamlarından Ebû Yûsuf'u (ö. 182/798) takip etmektedir. O; vakıfların ebedi olduğunu düșünüp vâkıfın nesli kesintiye uğradıktan sonra hayrî vakıflarda

11 George Hill, Kıbrıs Tarihi: Osmanlı ve İngiliz Ídaresi Dönemi 1571-1948, çev. Nazım Can Serbest (İstanbul: Türkiye İş Bankası Kültür Yayınları, 2016), 259-261; Hasan Samani, Tanzimat Devrinde Kıbrıs (1839-1878) (Ankara: Hacettepe Üniversitesi Sosyal Bilimler Enstitüsü, Doktora Tezi, 2006), 117-118.

12 Osmanlı Arşivi (BOA), 12 Numaralı Muhimme Defteri, [A. (DVNSMHM. d.12, h. 1215)]; Ali İhsan Karataş, "Osmanlı Devleti'nde Gayrimüslimlere Tanınan Din ve Vicdan Hürriyeti”, Uludağ Üniversitesi İlahiyat Fakültesi Dergisi 15/1 (2006), 274-75.

13 Recep Dündar, Kıbrıs Beylerbeyliği (1570-1670) (Malatya: İnönü Üniversitesi Sosyal Bilimler Enstitüsü, Doktora, 1998), 378.

14 Hüseyin Metin, Kıbrıs Tarihine Toplu Bir Bakış (Lefkoşa: Halkın Sesi Basımevi, 1959), 140-146; Bener Hakkı Hakeri, Başlangıcından 1878'e Dek Kıbrıs Tarihi (Lefkoşa: Kuzey Kıbrıs Türk Cumhuriyeti Milli Eğitim ve Kültür Bakanlığı, 1993), 253-255.

15 Halil Fikret Alasya, Kıbrıs Tarihi ve Kıbrıs'da Türk Eserleri (Ankara: Türk Kültürünü Araştırma Enstitüsü, 1977), 40; Kemal Çiçek, "Kıbrıs (Osmanlı Dönemi)”, Türkiye Diyanet Vakfı Íslam Ansiklopedisi (Ankara: TDV Yayınları, 2002), 25/375.

16 Hamidullah, İslam'da Devlet İdaresi, 134-135, 224 numaralı dipnot; Dündar, Kıbrıs Beylerbeyliği (1570-1670), 380.

17 Bahaeddin Yediyıldız, XVIII. Yüzyılda Türkiye’de Vakıf Müessesesi Bir Sosyal Tarih Incelemesi (Ankara: Türk Tarih Kurumu, 2003), 14-17. 
olduğu gibi bu vakıfların da diğer insanların faydasına sunulma maslahatını göz önünde bulundurarak bu tür vakıflara onay vermiştir.18

Müslümanlar ile birlikte gayrimüslimlerin de ailevî vakıf kurmalarında herhangi bir beis yokken gayrimüslimlerin hayrî vakıf kurmaları belli kısıtlamalara tâbi tutulmuştur. Müslümanlar kurdukları vakfın gelirini gerek Müslüman fakirlere gerekse gayrimüslim fukaraya bağışlayabilmekteydiler. Aynı şekilde zimmî şahıslar da vakıf gelirini hem kendi tebaasında bulunan fukaraya hem Müslüman fakirlerin istifadesine șart koșmalarında hukuksal anlamda bir beis yoktu. ${ }^{19}$ Her ne kadar farklı inanca sahip fukaraya vakfetmek sahih olsa da bu minvalde gayrimüslimler tarafından kurulmuş vakıflar yaygın değildi. Bu yüzden Kenan Yıldız bu gruba girenleri "aykırı vakıflar" olarak nitelendirmiştir.20 Yıldız'ın çalışma konusu yaptığı vakıflar, vakıf gelirlerini Müslümanlar dışındaki insanların girişine yasak olan Medine'deki fukaraya şart koşmuşlar. Nitekim her dinde muhtaç olana yardım etmek faziletli sayılmıştır. ${ }^{21}$ Fakat Hanefî alimlerine göre vakfın geçerli olmasının asıl amacı kurbet olduğundan, inançları gereği ister Müslüman isterse Hristiyan ve Yahudilerin Beytü'l-Makdis, zimmî fukara, Müslüman fukara gibi hayrî cihetlere vakfetmesi geçerliyken bir Müslümanın kilise ya da havraya ya da zimmî birinin hem kilise, havraya ya da İncil, Tevrat basımına hem de cami/mescide yapacakları vakıflar kurbet amacı gütmeyeceğinden sahih olarak kabul edilmemiştir. Bunun yanında zimmî biri kilise fukarası ya da kilise çalışanına sahip olduğu mülkü vakfederse sahih kabul edilecektir. ${ }^{22}$ İslam devletlerinde olduğu gibi Osmanlı devletinde de gayrimüslimlerin kiliseleri ya da havraları adına kurdukları vakıflar geçersiz sayıldığından vakıflar mensubu oldukları ibadethanelerin istifadesine sunmak için vakfiyelerine kilise fukarası ya da Yahudi fukarası gibi ibareler eklemişlerdi. ${ }^{23}$ Nitekim Kıbrıs'ta kurulan ve elimizde vakfiyesi olan gayrimüslim vakıfları arasında yalnızca bir tane bulunan Yahudi vakfında Yahudi fukarası tabiri diğer gayrimüslim vakıflarda ise kilise fukarası tabiri kullanılmıștır. ${ }^{24}$

Kıbrıs fethedildikten sonra harbî olduklarından Ada üzerindeki kilise faaliyetlerine son verilen Katoliklere ait başta Lefkoşa ve Magosa'dakiler olmak üzere en önemli katedraller ve kiliseler sahip oldukları mülkler ve vakıflarla camiye tahvil edilmiștir. Bunun yanında Osmanlı, savaşta kendilerine yardım ettikleri için Ortodoks ${ }^{25}$ ve Ermeni ${ }^{26}$ cemaatlerine gerek dinî gerekse sosyal ve siyasal haklar ve maddi olanaklar sağlamıştır. Katoliklere ait kilise ve manastırlardan bazıları Ortodoks Rum ve Ermenilere verilirken bazıları da sahip oldukları vakıf ve mülklerle birlikte satılarak elde edilen gelir devlet hazinesine yazdırılmıștır. ${ }^{27} \mathrm{Bu}$ mülkler gerek Müslüman gerekse gayrimüslimlere satılırken mülklerin içerisinde bazen harap duruma düşmüş bazen de sağlam kilise ve manastırların da olduğu görülmektedir. Osmanlı'nın ibadet etmeleri için Rum ve Ermenilere verdiği kiliseler yanında Kilise tarafından şahıs mülkü haline gelen bazı kilise ve manastırlar satın alınarak ibadet için kullanılmıştır. Lefkoşa'da Bici Aya Yanni Mesilogu isimli manastırı daha önce mîrî cânibinden edinen Mehmed Çelebi'den satın alan Polyo veled-i Kostantin adlı zimmî, burayı 12000 akçe bedel ile manastırın rahiplerine

18 Ali Himmet Berki, Vakıflar (İstanbul: Cihan Kitaphanesi, 1940), 1/92.

19 Berki, Vakıflar, 2/65.

20 Yıldız, "Aykırı Vakıflar", 143.

21 Berki, Vakıflar, I/50; Akgündüz, İslam Hukukunda ve İslam Tatbikatında Vakıf Müessesesi, 239.

22 Akgündüz, Íslam Hukukunda ve Íslam Tatbikatında Vakıf Müessesesi, 239-240; Konan, “Gayrimüslim Osmanlı Vatandașlarının Hukuki Durumuna İlișkin Bir Değerlendirme”, 177-178.

23 Yıldız, "Aykırı Vakıflar", 145.

24 Kıbris Şer'iyye Sicilleri 2, 50, h. 92 (Bundan sonra KŞS).

25 Ahmet C. Gazioğlu, "Kıbrıs'ta Türk Yönetiminin Hoşgörülü Davranıșı ve Hristiyan Toplumlara Tanınan Haklar”, Kıbrıs'ın Dünü-Bugünü Uluslararası Sempozyumu, Gazi Mağusa, 28 Ekim - 2 Kasım 1991, ed. Güner Göktuğ-Sabahattin İsmail (Kıbrıs'ın Dünü-Bugünu Uluslararası Sepozyumu, Ankara: Doğu Akdeniz Üniversitesi ve Van Yüzüncü Yıl Üniversitesi Yayınları, 1993), 215-229.

26 M. Akif Erdoğru, "Kıbrıs Ermenileri Üzerine Notlar (1580-1640)", Tarih Incelemeleri Dergisi 17/1 (01 Haziran 2002), 1-12.

27 Osmanlı Arșivi (BOA), 16 Numaralı Mühimme Defteri, [A.(DVNSMHM)], No. 16, h. 304; Osmanlı Arşivi (BOA), 31 Numaralı Mühimme Defteri, [A.(DVNSMHM)], No. 31, h. 468. 
satmıştır. ${ }^{28}$ George Hill, Ortodoks kilisesinin çok kısa zamanda gücünü toplayarak 15-20 yılda Osmanlı'nın el koyduğu bütün manastırları satın alarak ibadete açtığını iddia etmektedir. ${ }^{29}$

Ada'da Müslümanlar tarafından kurulan birçok vakfa ait akârâtın kiliseler ve kilise mülklerinin satın alınması yoluyla sağlandığı anlaşılmaktadır. Örneğin; Lala Mustafa Paşa Vakfı'na ait on üç kilise, üç tane manastır ve birtakım kilise mülkleri mevcuttur. Paşa bu kiliselerden bir tanesini Magosa'da, iki tanesini de Lefkoşa surlar içinde camiye çevirmiş geri kalanını mülk olarak kullanmıștır. ${ }^{30}$ Nitekim fetih sonrasında Magosa'da yapılan bir hesaplamada otuz bir tane kilisenin mevcut olduğu, kilise vakıflarının şer'an batıl olduğu için 30 tanesinin satılarak II. Selim'in (ö. 1574) Magosa'daki hayratı olan Aya Nikola/ Ayasofya-i Sağîr Camii giderlerine yetecek kadarının buraya bağlanması, Ayayorgi Kilisesi'nin de vakıfları ile birlikte reâyâya terkedilmesi ve gerisinin satılarak deftere kaydedilmesi istenmektedir. ${ }^{31}$

Kıbrıs 1571 yılında Osmanlı tarafından fethine kadar birçok devlet ve grubun kontrolüne geçmiştir. Bu devletler arasında Mısırlılar, Roma, Bizans, Müslümanlar, İngilizler, Lüzinyan, Venedik zikredilebilir. Kıbrıs'ı ele geçiren her medeniyet Ada'ya kendilerinden izler bıraktılar. ${ }^{32}$ Bazılarının izleri kısa sürede silinirken bazılarınınki günümüze kadar devam etmiştir. Vakıf hayratı da bu izlerden bir tanesidir. Nitekim Amerikalı araştırmacı Ronald C. Jennings bu konuda, Kıbrıs'ta Bizans hanedan üyeleri yanında çoğunluğu şahıslar tarafından meydana getirilmiş çok sayıda hayır kurumunun olduğunu belirtmektedir. Bunlar arasında hastaneleri, yetimhaneleri ve bakımevlerini saymaktadır. Nihayetinde yapılan çalışmalarda bu Hristiyan kurumları hakkında çok az bilgi bulunduğundan kesin bir hükme varmanın zor olduğunu belirtmektedir. ${ }^{33}$ Jennings, böylece Kıbrıs'taki Hristiyan vakıflarının geçmişini adadaki kontrolü 395-1185 yılları arasında olan Bizans'a kadar götürmektedir. Muhakkak ki Bizans'tan sonra gelen milletler de vakfa benzer hayratlar inşa etmişlerdir. Nitekim Osmanlı'nın Ada'yı ellerinden aldığı Venediklilerden önce burada uzun süre hüküm süren Lüzinyanlılar tarafından çok sayıda bina, köprü, kale, katedral, manastır ve kilise inşa edilmiş ve bu yapıların bir bölümü günümüze kadar gelmiştir. ${ }^{34} \mathrm{Bu}$ bağlamda biz de mezkûr dönemlerle ilgili belge elde edemezken yalnızca Osmanlı tarafından Ermeni, Rum Ortodoks ve Tûr-i Sîna başpiskoposlarına verilen beratlarda devletin kendilerine tanıdığı haklar sıralanırken "...zimmî tâifesinin ba'zıları hayatlarında patrike ve metrepolide ve piskoposa ve kiliselerine bir mikdâr șey vasiyyet eylediklerinde ba'dehu mürd olduklarında vârislerinden șer'le alıverilüp ve kilise ve manastırlarına müte'allık bağ ve bağçe ve çiftlik ve kadîmden temlîk olup vakf olunan buyût ve dekâkîn ve emlâk ve eşyâ ve nukûd ve davarlarına ve zabt [u] tasarruflarına düstûru'l-amel olup âhardan bir ferd müdâhale eylemeyeler..."35 ifadeleri arasında kullanılan "...kadîmden temlîk olup vakf olunan" tabirinden ve bazı mühimme defterlerinde açıkça zikredildiği gibi Osmanlı Kıbrıs'ı aldığında önceki devletlerden tevarüs eden manastır ya da kiliselerin mülkleri ve vakıfları mevcuttu. ${ }^{36}$

Kilise vakfı tabirini İslam hukuku açısından problemli olarak gören Lemerle P. ve Wittek P. isimli araștırmacılar 1491 tarihli Koutloumousiou Manastırı ile ilgili bir fermanda geçen bu ibareyi kilise mülkü olarak okumayı tercih etmişlerdir. ${ }^{37}$ Gayrimüslimler tarafından kurulan vakıflar ilk dönemlerde fukahâ nezdinde vakıf olarak değil de "vasiyet" ve "miras" bağlamında "kurbet" (hayr ve ve Allah'a yaklaşma) veya "ma'siyet" (günâh) yönünden ele alınmışlardı. ${ }^{38} \mathrm{Bu}$ konuda Molla Hüsrev (v. 1480):

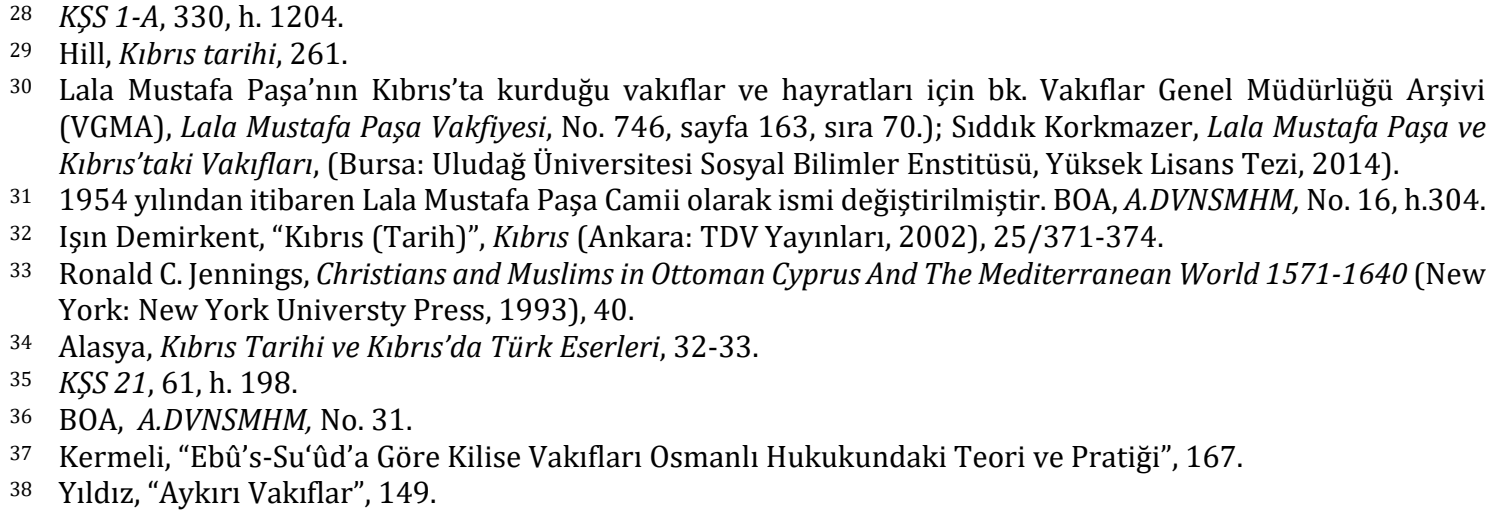

311954 yılından itibaren Lala Mustafa Paşa Camii olarak ismi değiştirilmiştir. BOA, A.DVNSMHM, No. 16, h.304.

32 Ișın Demirkent, “Kıbrıs (Tarih)”, Kıbrıs (Ankara: TDV Yayınları, 2002), 25/371-374.

33 Ronald C. Jennings, Christians and Muslims in Ottoman Cyprus And The Mediterranean World 1571-1640 (New York: New York Universty Press, 1993), 40.

34 Alasya, Kıbrıs Tarihi ve Kıbrıs'da Türk Eserleri, 32-33.

$35 \quad K S S$ 21, 61, h. 198.

36 BOA, A.DVNSMHM, No. 31.

37 Kermeli, “Ebû's-Su'ûd'a Göre Kilise Vakıfları Osmanlı Hukukundaki Teori ve Pratiği”, 167.

38 Yıldız, "Aykırı Vakıflar", 149. 
“...malının üçte birini fakirlere veya köle âzâd etmeye yâhûd Beyt-i Makdis'de (Mescid-i Aksâ'da) kandil yakmaya vasiyyet etmesi böyledir. Bu vasiyyet, ittifakla sahih olur. Çünkü diyanette hepsi ittifak etmişlerdir. Yâhûd vasiyyet onlara göre, kurbet; bize göre, ma'siyettir. Meselâ; hanesini Yahudiler için havra, Hıristiyanlar İçin kilise veya Mecûsîler için âteşgede yapması böyledir. Bu vasiyyet mutlaka sahih olur. Yâni gerek kendileri için vasiyyet ettiği topluluğu belirtsin, gerekse belirtmesin fark etmez. İmâmeyn (Rh. Aleyhimâ)'e göre; ancak belli kimseler için vasiyyet ederse, sahîh olur. Îmâmeyn'in delili şudur: Bu, ma'siyeti vasiyyet etmektir ve bunun yerine getirilmesinde ma'siyeti kabul vardır. Ma'siyette yapılacak iş, onu reddetmektir. Yoksa, ma'siyetin yerine getirilmesi değildir. Îmâm A'zam (Rh.A.)'ın delili şudur: Mu'teber olan, onların hakkında diyanetleridir. Çünkü biz, onları diyanetleri ile baş başa bırakmakla emr olunduk. Bu vasiyyet, onlara göre kurbettir. Şu hâlde sahîh olur."39

Sözleriyle kendisinden önceki alimler gibi gayrimüslim vakıflarına hukuki bir zemin bulma çabasındadır. Nitekim Osmanlı toprak kanununu yeniden düzenleyen Şeyhülislam Ebussuûd Efendi, toprağın manastırlar ve kiliseler tarafından zimmete geçirilmesini engellemek için çalışmış, ${ }^{40}$ bunun yanında gayrimüslim vakıflar hakkındaki durumu sağlam bir temele oturtmak için de klasik İslam hukukunu yeniden yorumlayarak yeni kanunlar vaz' etmiştir. Bu bağlamda geçersiz olan hayrî gayrimüslim vakıflarına fukara tabirini ekleyerek ve ehlî vakıf statüsü kazandırarak çözüm yolu bulmuştur. Ebussuûd, özellikle Balkanlar'daki kilise mülklerinin durumunu netleştirerek arazilerin rakabe ve tasarruf hakkı arasındaki farkı açıç̧a ortaya koymuştur. Bu bağlamda kiliseler ellerinde olan mülklerin yalnızca ekip biçme hakkına sahip olduklarından ve mülkün asıl sahibinin devlet adına padişah olduğundan kilise vakıf ve mülklerinin müsadere edilebilmesinin yanında toprağa mâlik olmayan kiliselerin vakıf da kuramayacağını açıkça ortaya koymuştur. Kiliselerin eski vakıf mülklerinin kullanımına devam edebilmeleri için de devlete vergi vermeleri gerekmektedir. ${ }^{41}$

Osmanlı'daki gayrimüslim ve kilise vakıfları hakkında gözden kaçırılmaması gereken bir konu örfi hukuk ile farklı coğrafya ve devirlerde verilen kararların bütün zamana yayılmasının araştırmacıyı hataya düşüreceğidir. ${ }^{42}$ Çünkü Osmanlı Devleti Balkanlar'da bulunan manastırların vergi vermesini zorunlu kılarken Kıbrıs'ta ise kiliseleri, sahip oldukları mülkler için öşür vergisi vermekten muaf tutmakta idarecilerin buna riayet edip kilise mensuplarına baskı yapmamasını verdiği beratlarda vurgulamaktaydı. ${ }^{43}$

Ebussuûd'un 17 Kasım 1569 tarihli kararıyla manastır vakıflarının müsadere edilmesi hakkında yayımlanan fermanda hangi kilise vakıflarının meşru olmadığı hakkında şu pasaj bulunmaktadır.

“...memâlik-i mahrûs[e]lerimde olan kiliseler vakfi içün müftî-i zamândan istiftâ olundukta zimmîler tasarruf etdikleri tarlaları ve çayırları ve mülk bağ ve bağcelerin (2) ve değirmenlerin ve evlerin ve dükkânların kiliselerine vakf etmek aslâ sahîh olmak ihtimâli yokdur cinâyet-i 'azîmdir alınmak lâzımdır kuzât vakfi ye verirler ise ol dahi kat'â (3) sahîh değildir vakıfları ve yâhud vârisleri hayâtda ise mülkeridir alurlar tasarruf

39 Hüsrev, Gurer ve Dürer, çev. Arif Erkan (İstanbul: Eser Neşriyat, 1979), 4/399-400.

40 Osmanlı döneminde Ortodoks kilisesine verilen haklar bağlamında bunlar gayrimüslim tebaanın temsilcileri konumuna geldiler. Sahip oldukları mülkler ve bu mülkler üzerindeki imtiyazlardan dolayı zengin duruma geldiler. Kilise ve manastırlar sahip oldukları mülkler onların güçlenmesine ve bu güç nedeniyle yönetim için tehlike arzetmesi sadece Osmanlı için değil Bizans İmparatorluğu döneminde de olmuş ve Nikhephoros Phokas (963-969), 964 yılında çıkardığı hususî bir kanun ile kilise ve manastırlar ile ruhani liderlerinin arazi edinimini ve gereksiz olarak inșa edilen yeni kilise ve manastırların kurulmasını yasaklamıștır. Ancak Phokas bir suikaste kurban gitmiş ve yerine imparator olan İonnes Çimiskes (969-976), söz konusu kanunu iptal etmiștir. Georgije Ostrogorski, Bizans Devleti Tarihi, çev. Fikret Ișlltan, 7. b., (Ankara: Türk Tarih Kurumu Basımevi, 2011), 267-68.

41 Barkan'dan alıntılayarak "Lâkin defâtir-i kerîme-i kadîmede arazî-i memâlik-i mahmîyenin tefâsîl-i ahvâline taarruz olunmayub ve künh-i hâkîkatı nedir 'öşriye midir haraciye midir ve tasarruf idenlerin mülkleri midir değil midir keşif ve beyan olunmaduğı sebebden reâya ellerinde olan yerleri öşriye sanub sekizde bir virmede nizâ' idüb ve kendilerin mülkleri sanub sâir mülkleri gibi biribirine bey' ve şirâ idüb ba'zı dahi zu'mlarınca vakf idüb vülât ve hükkâm dahi hakîkat-ı hâle vâkıf olmayub hılâf-ı şeri'at-ı şerîfe bey' ve şirâ hüccetleri ve vakfi yeler virmek- le nizâm-ı umûra ve mesâlih-i cumhûra halel-i 'azîm gelmeğin.” Kermeli, "Ebû's-Su'ûd'a Göre Kilise Vakıfları Osmanlı Hukukundaki Teori ve Pratiği”, s. 170.

42 Kermeli, "Ebû's-Su'ûd'a Göre Kilise Vakıfları Osmanlı Hukukundaki Teori ve Pratiği”, 165.

$43 K S S$ 38, 30, h. 19. 
ederler mîrî cânibine hukûk-i şer'îyye ve 'örfiyelerin verirler eğer vakıfları ve vârisleri hayâtda değil ise cümle (4) beytü'l-mâle 'â'iddir alınub bahâları ile tâlib olanlara bey' olunmak vâcibdir eğer mezkûrlar emlâk-i sahîha-i mezkûrelerin kiliselerine vakf itmiş olmayup ruhbânlarına, fukarâlarına ve yâhud (5) köprülere ve çeşmelerine vakf etdiler ise ve kuzât vakfiyetlerine sıhhat üzre hükm edüb sicill-i sahîh etdiler ise sahîhdir şer îdir ellerinden alınmaz şerâ'it-i mezbûre üzre tasarruf edüb (6) bir birinin bî-kusur hukûk-ı şer'iyyesin ve 'örfîyesin verirler deyû fetva verdiler imdi kazâ-yı mezbûrda kilise vakfı olmayub keferenin ve ruhbânların kendü mülkleri olan yerlerine dahi olunmak câ'iz değildir (7) kilise vakfı ismiyle tasarruf olunan yerler bu bâbda verilen fetvâ-yı şerîfe mucebince ellerinden alınub tapu ile āhara verilüb il verdüği tapu ile 'öşr ve rüsûmun vermek şartı ile girü kendüler (8) kabul ederler ise verilüp ve mukāta'aları fesh olunub 'öşrü ve resimleri alınmasın emr edüb..." ${ }^{4}$

Yukarıdaki pasajdan da sarih olarak anlaşılmaktadır ki eğer mülkler manastır keşişleri, fukara, köprü, çeşme gibi hayratlar için vakfedilmişlerse geçerli, doğrudan kilise ve manastırlar için vakfedilmişlerse kadılar tarafından vakfiyeleri kayda geçirilmiş olsa dahi geçersizdir. Bu geçersiz vakıfların mülkleri eski sahipleri ya da varisleri hayatta iseler kendilerine geri verilebilecek aksi durumda mülkler mîrî arazi sayılacağından müsadere edilebilecektir.

Ebussuûd'un kilise ve manastır üyeleri tarafından vakfedilecek bir mülkün durumu hakkında aşağıda verilen fetvasında, ekilip biçilecek mülkler dışında ve mevkufun aleyhin kilise olmaması şartı ile değirmen, bağ, bahçe ve hayvanların kilise ziyaretçilerinin ve fukaranın yararına vakfedilebileceği, bunun yanında vakfın idaresinin rahiplerde olacağı rahipler ölünce idarenin diğer rahiplere geçeceği kaydedilirse vakfın sıhhatinde bir değişiklik olmayacağı belirtilmiștir.

\footnotetext{
“Mes'ele: Ba'zı zimmîler bir manastır râhibleri olduklarında, mezburların ellerinde olan mülk davarların ve bağların ve bahçelerin ve değirmenlerin il kâtibi mezburların ellerinden alıp, yine mezburlara bey' edip, mezbur zikr olunan emlâki mezbur manastırın fukarasına ve âyende ve revendesine vakf eylese, ba'de zamanın mezbur vakfa şer'an hâriçten kimse dahle kadir olur mu?

Elcevap: Vakfettikleri davar ve bağ ve bahçe ve değirmen ve dükkân makülesinden olup, manastıra vakf etmeyip, gelen giden fukaraya vakf edicek asla dahi olunmaz. Tarlalar ve mezra'alar ise asla vakfa kabil değildir. Amma anı dahi mîrîden tapuya alıp rahibler tasarruf edip şâir re'âyâ gibi cemî hukukunu verdikten sonra kimse dahi etmeye. Rahipler fevt oldukta, yerinde kalanlar tasarruf edeler" deyu defterde kayd olunucak ana dahi dahi olunmaz, vakıf adına olmayıcak." 45
}

Yukarıda verilen fetvalar bütün olarak değerlendirilecek olursa; gayrimüslimler tarafından kilise, havra, manastır gibi mabetlerde bulunan din adamları, fukara ve gelip geçen kişiler yararına vakıf kurmak şer’an sahihtir. Fakat mevkufun mülkiyeti mabetlerin şahsına geçmemekte yalnızca rahipler adına kurulmuşsa ondan sonraki rahiplere bırakılmakta ya da vâkıfın tüzel kişiliğinde kalmaya devam etmektedir. Aslında Ebussuûd Efendi burada fetvaları verirken yalnızca İslami hassasiyetleri göz önünde bulundurmamış, Balkanlar özelinde olmak üzere Kilise'nin Bizans döneminde sebep olduğu sıkıntıları bildiğinden bağışlarla çok fazla zengin olup devletin karşısına bir güç olarak çıkmasının önüne geçmeye çalışmış ve kontrol altında tutma gayreti göstermiştir. ${ }^{46}$ Kıbrıs'ta ise kilise nüfuzunun ada dışına sirayet etme ihtimali düşük olduğundan daha rahat hareket etmelerine olanak sağlamıştır. Kiliselerin cemaatleri ile ilgili konularda serbestçe hareket etmelerine izin verme ve kendi inançlarına göre yargılanma, miras bırakma ve ticaret yapma hakkı tanımanın yanında Ada'da düzen oturduktan ve halka yeterli ibadet yeri verildikten sonra Osmanlı'nın diğer bölgelerinde olduğu gibi burada da kiliselerin inşa ve onarımı belli kurallara tâbi tutulmuştur. Bunlar iki türlüdür. İlki eğer kilise deprem, tufan vb. doğa felaketi neticesinde yıkılmışsa yerel yöneticiler ve mimar tarafından yapılacak keşif neticesinde İstanbul'dan gerekli izinler alındıktan sonra eski şekline herhangi bir eklenti yapılmadan yeniden inşa edilecektir. İkincisi ise kiliselerin sıva, cam ve kiremitlerinin

44 Kermeli, "Ebû's-Su'ûd'a Göre Kilise Vakıfları Osmanlı Hukukundaki Teori ve Pratiği”, 171

45 Mehmet Ertuğrul Düzdağ, Fetvalar: Ebusuud Efendi (İstanbul: İ.İ.A Yayınları, 1972), 112.

46 Ceyhan, Osmanlı Devleti'nde Gayrimüslimlerin Mülk ve Vakıf Edinimi (18. yüzyıl), 175. 
yıpranması sonucu yapılacak tadilatlar ise yerel yöneticilerin onayına bırakılmıştır. ${ }^{47}$ Yerel yönetime verilen bu hak bazı istismarlara neden olmuş, yerel yöneticilerin kiliselerden yasal sınırın üzerinde vergi alma, vefat eden ruhban sınıfının mülküne el koyma, tadilat edilecek kiliseler konusunda mevzuatın dışına çıkma hatta yeni kilise inşaatına göz yummaları üzerine yöneticiler İstanbul'dan uyarılmış ve Ada'da bulunan yabancı konsolosluk mensubu kişiler ile burada yasal olmadan çalışan reâyânın kiliselere mülk ve vakıf aktarımı yaptıkları bildirilip buna engel olunması istenmiștir. ${ }^{48}$ Osmanlı’nın zamanla Batı karşısında güç kaybetmesi ve içişlerine müdahale edilmesi üzerine gayrimüslimlere daha fazla hak verilmiştir. Bu bağlamda Ada üzerinde ilk kilise inşaat izni 5 Ramazan 1273/ 29 Nisan 1857 tarihinde Mesarya'nın Mandersi köyünde yapılmak üzere alınmıştır. ${ }^{49}$

\section{Zimmî Tebaanın Kurduğu Vakıflar ve Özellikleri}

Bundan sonra oluşturduğumuz iki tablo eşliğinde Kıbrıs'ta gayrimüslimler tarafından kurulmuş ve vakfiyesi elimizde olan şahıs vakıfları ile vakfiyeleri elimizde olmayıp vakfa sahip olan kiliseleri iki başlık altında inceleyeceğiz.

\subsection{Sahıs Vakıfları}

Bu başlık altında Tablo 1'de Kıbrıs'ta şahıslar tarafından kurulmuş ve elimizde vakfiyesi olan on vakıf ile vakfiyesi iptal edildiğinden tabloya almadığımız bir vakfı inceleyeceğiz. Tablo 1 'de görüldüğü gibi vâkıf, mevkuf, mevkufun aleyh, vakıf şartları, mütevellinin kime ait olacağı, vâkıfın hangi dine mensup olduğu ile vakfın șer'iyye siciline kayıt tarihi verilmiștir. Bu yöntemle daha önce yapılan çalışmada verilen bilgilerin tekrarının önüne geçilmeye çalışılmıştır. Tablo 1 ve vakıf özellikleri ilgili değerlendirme aşağıda yapılmıștır.

Tablo 1: Kıbrıs'ta şahıslar tarafından ailevî ve hayrî amaçlarla oluşturulmuş vakıflar.

\begin{tabular}{|c|c|c|c|c|c|}
\hline $\begin{array}{l}\text { Sira } \\
\text { No }\end{array}$ & $\begin{array}{l}\text { Vâkfın } \\
\text { adı }\end{array}$ & $\begin{array}{l}\text { Mevkuf, Mevkufun Aleyh ve } \\
\text { Şartları }\end{array}$ & Tevliyet & Milleti & $\begin{array}{l}\text { Vakfiyenin } \\
\text { Tarihi }\end{array}$ \\
\hline 1 & $\begin{array}{l}\text { Rafael } \\
\text { veled-i } \\
\text { Lazari50 }^{5}\end{array}$ & $\begin{array}{l}\text { Lefkoşa Kalesi'nde Zeynelabidin } \\
\text { Efendi Mahallesinde İlya isimli } \\
\text { Yahudi'den satın aldığı } 2 \text { bâb } \\
\text { fevkânî ve } 6 \text { bâb tahtânî mülk } \\
\text { dâreyni (iki ev) havlusu ve } \\
\text { kuyusu ve harmanı ve bütün alet } \\
\text { ve edevatıyla vakıf olup Yahudi } \\
\text { fukarasına kiraya verilerek elde } \\
\text { edilen gelirden yıllık } 120 \text { akçe } \\
\text { Lefkoşa'daki Ayasofya Camii } \\
\text { aydınlatılması için yağ kandili } \\
\text { alınacaktır. Geri kalan miktarla } \\
\text { mevkuf tamir edilecektir. }\end{array}$ & $\begin{array}{l}\text { Kendisi } \\
\text { kendisinden } \\
\text { sonra evlatları, } \\
\text { evlatları da son } \\
\text { bulunca Yahudi } \\
\text { milletinden } \\
\text { birisi mütevelli } \\
\text { olacaktır. }\end{array}$ & Yahudi & $\begin{array}{l}1 \text { Zilkade } 1016 / \\
17 \text { Şubat } 1608\end{array}$ \\
\hline 2 & $\begin{array}{l}\text { Elyasi ve } \\
\text { Sava } \\
\text { veled-i } \\
\text { Avraşim } 51\end{array}$ & $\begin{array}{l}\text { Lefkoşa'nın } \\
\text { köyünde bulunan } 1 \text { dönümlük } \\
\text { ortak ağaçlı bahçelerini ve her } 15 \\
\text { günde salı günü } 2 \text { saatlik sulama } \\
\text { hakkı ile Girne'de bulunan } \\
\text { Kalyondi Manastırı'nda bulunan } \\
\text { fukaraya elbise ve diğer } \\
\text { ihtiyaçlarını görmek üzere } \\
\text { vakfetmistir. }\end{array}$ & \begin{tabular}{lr}
\multicolumn{2}{l}{ Manastırın } \\
rahibi & Papa \\
Kalatko & ve \\
ondan & sonra \\
yerine & gelecek \\
rahibi & \\
mütevelli & \\
olacaktır.
\end{tabular} & Ermeni & $\begin{array}{l}9 \text { Safer 1111/ } 6 \\
\text { Ağustos } 1699\end{array}$ \\
\hline
\end{tabular}

47 KŞS 41, 206, h. 283; Harry C. Luke, Türk idaresinde Kıbrıs 1571-1878, çev. Ali Çakıroğlu (Lefkoşa: Galeri Kültür Yayınları, 2014), 22-23.

$48 \quad$ KŞS 27, 153, h. 333.

49 Osmanlı Arşivi (BOA), Irâde-Hariciye, [İ.HR], No.142, Gömlek No. 7480.

$50 K S S S$ 2, 50, h. 92.

$51 K S S S$ 6, 103, h. 296. 
Osmanlı Kıbrıs'ında Gayrimüslim ve Kilise Vakıfları

\begin{tabular}{|c|c|c|c|c|c|}
\hline 3 & $\begin{array}{l}\text { Hristofi } \\
\text { veled-i } \\
\text { Lefteri }^{52}\end{array}$ & 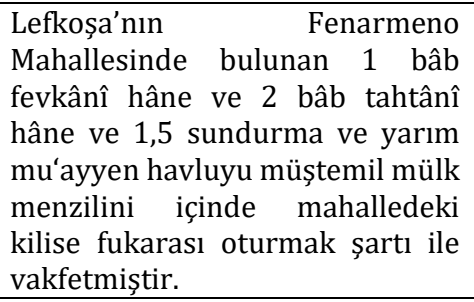 & $\begin{array}{l}\text { Kilisenin diğer } \\
\text { vakıflarına } \\
\text { mütevelli olan } \\
\text { kissi buna da } \\
\text { mütevelli } \\
\text { olacaktır. }\end{array}$ & Rum & $\begin{array}{l}15 \text { Receb } 1133 / \\
12 \text { Mayıs } 1721\end{array}$ \\
\hline 4 & $\begin{array}{l}\text { Hristino } \\
\text { bint-i } \\
\text { Kostanti } \\
53\end{array}$ & $\begin{array}{l}\text { Lefkoşa'nın } \frac{\text { Fenarmeno }}{\text { Mahalesinde bulunan } 3 \text { bâb }} \\
\text { tahtânîhâne ve } 1 \text { sundurma ve bir } \\
\text { mikdâr havlu ve meyveli ve } \\
\text { meyvesiz ağaçlarıyla } 1 \text { mülk } \\
\text { menzilini vakfederek içinde Çiko } \\
\text { Manastırı fukarası oturmak üzere } \\
\text { şartı koşmuştur. }\end{array}$ & $\begin{array}{l}\text { Çiko Manastır } \\
\text { Evkâfı } \\
\text { Mütevellîsi }\end{array}$ & Rum & $\begin{array}{lr}1 & \text { Ramazan } \\
1133 & / 26 \\
\text { Haziran } & 1721\end{array}$ \\
\hline 5 & $\begin{array}{l}\text { Lino bint- } \\
\text { i Dimitrit54 }\end{array}$ & $\begin{array}{l}\text { Lefkoşa'nın Ayaandoni } \\
\text { Mahallesinde bulunan } 1 \text { bâb } \\
\text { fevkânî, } 4 \text { bâb tahtânî hâne ve } \\
\text { tahtânî ve fevkânî } 2 \text { sundurma ve } \\
\text { dolap kuyusu ve bir mikdâr havlu } \\
\text { ve meyveli ve meyvesiz ağaçlı } \\
\text { mülk menzilini içinde Ayaandoni } \\
\text { Kilisesi fukarası oturmak üzere } \\
\text { vakfetmiștir. }\end{array}$ & $\begin{array}{l}\text { Kilisenin diğer } \\
\text { vakıflarına } \\
\text { mütevelli olan } \\
\text { kişi buna da } \\
\text { mütevelli } \\
\text { olacaktır. }\end{array}$ & Rum & $\begin{array}{l}22 \text { Rebiülâhir } \\
1133 \text { / } 20 \text { Şubat } \\
1721\end{array}$ \\
\hline 6 & $\begin{array}{l}\text { Maryo } \\
\text { bint-i } \\
\text { Markaro } \\
55\end{array}$ & $\begin{array}{l}\text { Lefkoşa'nın } \\
\text { Mahallesinde bulunan } 1 \text { avlu } \\
\text { içinde bulunan } 3 \text { bâb tahtânî } \\
\text { hânesiyle ve su kuyusu, meyveli } \\
\text { ve meyvesiz ağaçlarla mülkünü } \\
\text { Maşara Manastırna vakfederek } \\
\text { geliri ile ruhbanlar ve } \\
\text { misafirlerine harcanmak üzere } \\
\text { vakfetmiștir. }\end{array}$ & $\begin{array}{l}\text { Manastırın } \\
\text { gamnozu } \\
\text { mütevelli } \\
\text { olacaktır. }\end{array}$ & Rum & $\begin{array}{l}13 \text { Rebiulevvel } \\
1150 / \quad 11 \\
\text { Temmuz } 1737\end{array}$ \\
\hline 7 & $\begin{array}{l}\text { Mayram } \\
\text { bint-i } \\
\text { Sarkiz }^{56}\end{array}$ & 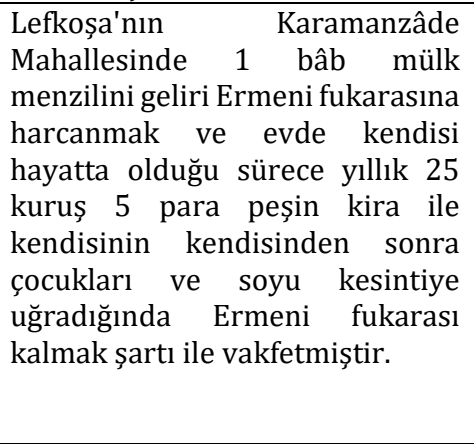 & $\begin{array}{l}\text { Asvador veled-i } \\
\text { Papas Mıgırdıç } \\
\text { mütevelli } \\
\text { olacak. Ondan } \\
\text { sonra da } \\
\text { çocukları. Nesli } \\
\text { son bulunca } \\
\text { Ermeni } \\
\text { fukarası } \\
\text { kadının izniyle } \\
\text { mütevelli } \\
\text { olacaktır. }\end{array}$ & Ermeni & $\begin{array}{l}11 \\
\text { Cemâziyelâhir } \\
1231 / \text { } 29 \\
\text { Nisam } 1816\end{array}$ \\
\hline 8 & $\begin{array}{l}\text { Yorgi } \\
\text { veledi } \\
\text { Hıristofi } \\
\text { veledi } \\
\text { Atam } 57\end{array}$ & $\begin{array}{l}\text { Tuzla'nın Dohni/ Taşkent } \\
\text { Köyünden vefat eden Yorgi veledi } \\
\text { Hıristofi veled-i Atam'ın köyde } \\
\text { bulunan Aya Eleni Kilisesi } \\
\text { fukaraları için malının sülüsünü } \\
\text { vasiyet edip kilise mütevellisi } \\
\text { Hıristofi veled-i Yorgi'ye bir } \\
\text { hüccet teslim etmiştir. Yorgi } \\
\text { veledi Hıristofi veled-i Atam'ın } \\
\text { vefat etmesi üzerine kilise } \\
\text { mütevellisinin kadıya başvurması } \\
\text { üzerine terekesi çlkartılmış ve }\end{array}$ & $\begin{array}{l}\text { Hıristofi veled-i } \\
\text { Yorgi }\end{array}$ & Rum & $\begin{array}{l}19 \text { Rebiulevvel } \\
1272 / 29 \text { Kasım } \\
1855\end{array}$ \\
\hline
\end{tabular}

$52 K S S$ 10, 105, h. 453.

$53 K S S S 10,127$, h. 541.

$54 \quad K S S S ~ 10,92$, h.376.

$55 K S S S$ 15, 37, h. 162.

$56 K S S S 29,46$, h. 84.

57 KŞS 44, 46, H. 67. 
Sıddık Korkmazer

\begin{tabular}{|c|c|c|c|c|c|}
\hline & & $\begin{array}{l}\text { terekeden sülüsü } 13309 \text { guruş, } 30 \\
\text { para kilise mütevellisine teslim } \\
\text { edilmiștir. }\end{array}$ & & & \\
\hline 9 & $\begin{array}{l}\text { Mario } \\
\text { binti } \\
\text { Yanni }^{58}\end{array}$ & $\begin{array}{l}\text { Tuzla'nın İlarozoz Mahallesinde } \\
\text { bulunan } 2 \text { bâb tahtânî önünde } \\
\text { sundurmalarıyla } 2 \text { bâb fevkânî } \\
\text { oda ki toplam } 4 \text { bâb oda ve } \\
\text { meyveli ve meyvesiz ağaçlarla bir } \\
\text { mikdâr havlıyı müştemil } 1 \text { bâb } \\
\text { menzilini ve kazâ-i mezkûra } \\
\text { muzâfe Aleminyo Köyünde } \\
\text { bulunan harman tarlası olarak } \\
\text { bilinen yerde } 4 \text { kök harnup ağacı } \\
\text { ile aynı köyde Kafallodya denilen } \\
\text { tarlada } 1 \text { kök ve Dolyeri denilen } \\
\text { yerde } 1 \text { kök ve Heci Belaki } \\
\text { tarlasında } 1 \text { kök ve Menoya } \\
\text { köyünde } 1 \text { kök ki toplam } 4 \text { kök } \\
\text { zeytin ağaçlarını; menzil } \\
\text { mütevelli tarafından kiraya } \\
\text { verilecek, ağaçların da sslahı da } \\
\text { mütevelli tarafından yapılacaktır. } \\
\text { Menzilin kirası ve ağaçların } \\
\text { meyvesinden elde edilecek gelir } \\
\text { ise mahalledeki Aya Lazaroz } \\
\text { Kilisesi fukarasına yemek } \\
\text { verilmek üzere vakfetmiştir }\end{array}$ & $\begin{array}{l}\text { Hıristoğlu } \\
\text { veled-i } \\
\text { Konomidi }\end{array}$ & Rum & $\begin{array}{ll}27 & \text { Şaban } \\
1275 / 1 & \text { Nisan } \\
1859 & \end{array}$ \\
\hline 10 & $\begin{array}{l}\text { Tüccar } \\
\text { Heci } \\
\text { Zaharka } \\
\text { veled-i } \\
\text { Heci Sava } \\
\text { veled-i } \\
\text { Atam59 }\end{array}$ & $\begin{array}{l}\text { Lefkoşa'nın } \\
\text { Myaandoni } \\
\text { Mahallesinden vefat eden Tüccar } \\
\text { Heci Zaharka veled-i Heci Sava } \\
\text { veled-i Atam vefat etmeden } \\
\text { malının üçte birlik kısmı olan } \\
12800 \text { kuruşunu Ayaandoni, } \\
\text { Ayakasyano, Ayaluka, Ayayorgi, } \\
\text { Kafesli, Fenaromeni, Ayayani, } \\
\text { Başmahalle ve Ayasava Kiliseleri } \\
\text { fukarasına eşit şekilde } \\
\text { paylaştırarak vasiyet etmiștir. }\end{array}$ & $\begin{array}{l}\text { Aya Andoni } \\
\text { Kilisesi } \\
\text { mütevellisi } \\
\text { Nikolaci veledi } \\
\text { Heci Yorgi, } \\
\text { Ayakasyano } \\
\text { Kilisesi } \\
\text { mütevellîsi } \\
\text { Boyacl Yorgi } \\
\text { veled-i Luka, } \\
\text { Ayaluka } \\
\text { Kilisesi } \\
\text { mütevellisi } \\
\text { Filipi veled-i } \\
\text { Heci Petro, } \\
\text { Ayayani } \\
\text { Kilisesi } \\
\text { mütevellisi } \\
\text { Heci Filipi } \\
\text { veledi Heci } \\
\text { Yakomi, } \\
\text { Başmahalle } \\
\text { Kilisesi } \\
\text { mütevellisi } \\
\text { Yanakoveledi } \\
\text { Togofari, } \\
\text { Ayasava } \\
\text { Kilisesi } \\
\text { mütevellsi } \\
\text { Mihaili veledi } \\
\text { Hıristofi }\end{array}$ & Rum & $\begin{array}{l}3 \text { Şaban 1279/ } \\
24 \text { Ocak } 1863\end{array}$ \\
\hline
\end{tabular}

$58 K S S S 45,5$, h. 8.

$59 \quad K S S$ 46, 76, h. 108. 
Gayrimüslimlerin ailevî ve kurbet amacı güden hayrî vakıf kurmalarında Müslüman vakıflarda aranan reşit, âkıl bâliğ, hür olmak yanında mevkufa mâlik ve mevkufun ayn olması gibi şartlar da aranmıştır.60

Kıbrıs Şer'iyye Sicilleri'nde yaptığımız incelemede Osmanlı döneminde sicillere kaydedilmiș ve birisi vakıf kurmak için gerekli șartları yerine getirmediğinden iptal edilmiș on bir vakıf kaydı bulunmaktadır. Tablo 1'de görüldüğü gibi, bunlardan bir tanesi Yahudi, iki tanesi Ermeni, sekiz tanesi de Rumlar tarafından kurulmuştur.

Kayıtlarda geçen ilk gayrimüslim vakfı 1 Zilkade 1016/17 Şubat 1608 tarihli Lefkoşalı Yahudilerden Rafael veled-i Lazari'ye aittir. ${ }^{61} \mathrm{Bu}$ vakıf bazı özelliklerinden dolayı diğer vakıflardan farklılık arz etmektedir. On bir vakıf içerisinde tek ailevî/ zürrî vakıf budur. Vâkıf mütevelliliği kendine ve kendinden sonra çocuklarına onların son bulması ile de kadı onayı ile Yahudi birine ait olmasını ve Yahudi fukarasının mevkufta oturmasını șart koșmuștur. Diğer vakıflardan farklı olan bir diğer yönü ise başka bir dinin mabedine vakıfta bulunmuş olmasıdır. Vâkıf, vakıf gelirinden Lefkoşa'daki Ayasofya Camii'nin aydınlatılması için yıllık 120 akçe şart koşmuştur. Bir gayrimüslimi buna sevk eden etmenleri ve kâdının kurbet amacı gütmeyen bu vakfiyeyi onaylama niyetini bilemiyoruz. Vâkıfın mevkufta Yahudi fukarasının oturma şartını koşmuş olması bir anlamda hayrî işlev gördüğünden dolayı bu vakfın onaylanmış olması muhtemeldir. Başka bir dinin mabedine vakıfta bulunması bakımdan "aykırı vakıf"62 olarak nitelendirilebilir. Osmanlı topraklarında bu özelliğe sahip tek vakıf bu değildir. Nitekim Kenan Yıldız, yaptığı araştırmalarda Osmanlı döneminde gayrimüslimler tarafından önemli bir kısmı Haremeyn fukarası için kurulmuş on dört tane vakıf tespit etmiştir. ${ }^{63}$

Kıbrıs'taki Hristiyan vakıflarına bakıldığında vâkıfın, kurduğu vakfa mütevelli olarak mevkufun aleyh kilisenin fukarasının mensubu olduğu kiliseye ait papaz ya da vakıf mütevellisini vakfına da mütevelli olarak şart koștuğu görülmektedir. Sadece Mario binti Yanni tarafından kurulan vakıfta mütevelli Hıristoğlu veled-i Konomidi isimli gayrimüslim zikredilmektedir. Ancak onun da görevinin ne olduğu tam olarak belli olmadığından mezkûr şartı taşıyan biri olma ihtimali de vardır. Mütevellinin, görevi ya da hayatı son bulduğunda mütevellilik; o makama ya da o göreve gelen kişiye devredilecektir.

Mevkuflar incelendiğinde on vakıfta da gayrimenkullerin vakfedildiği görülmektedir. Sekiz tane vakfa ait mevkuf içerisinde farklı kat sayısına binaen farklı sayıda oda, bahçe, ağaç vb. barındıran on menzil yanında bir tane de ağaçlı ve sulama hakkı bulunan bahçe vakfedilmiştir.

Vakıfların içerisinde nukûd vakfı bulunmamakla birlikte vefat ettikleri zaman kiliselere vasiyette bulunan iki kişiye ait miras, vefatlarından sonra kadı tarafından atanan bir bilirkiși eşliğinde bütün servetlerine bir değer biçilerek diğer varislerine pay edilmiş ve üçte birlik kısmı ise vasiyetleri gereği kilise mütevellilerine teslim edilmiştir. Bu tür vakıf kuran Tüccar Heci Zaharka veled-i Heci Sava veled-i Atam ${ }^{64}$ ile Yorgi veledi Hıristofi veledi Atam ${ }^{65}$ isimli gayrimüslim vâkıflar toplamda 26209 kuruş 30 para değerindeki mülklerini kilise fukaralarına bağışlamışlardır.

Kıbrıs'taki gayrimüslim on bir vakıftan şartları taşımadığı için iptal edilen vakıf, Avraşim adlı zimmî tarafından kurulan Lefkoşa'ya bağlı İnehoryo Köyü Kilisesi vakfıdır. İptal edilmesinin sebebi ise şöyledir: 1045 tarihli bir mahkeme kaydında mezkûr kilisenin eski ve yeni mütevellileri aralarındaki bir anlașmazlıktan dolayı kadı huzuruna çıkmaktadırlar. Kilisenin mevcut mütevellisi Mihail veledi Kostantin esbak mütevelli Pavlo veledi Zorzi'nin bundan kırk yıl önce Avraşim isimli zimmî tarafından aynı köyde sınırları beyan edilen yerde on beş günde bir cuma gecesi beş saatlik sulama hakkıyla birlikte üç dönüm arzını ${ }^{66}$ hayatta olduğu dönemde kiliseye vakfedip mütevelliliğine de kilisenin mütevellisi rahip Pavlo veledi Zorzi'yi tayin

60 Berki, Vakıflar, I/46-66.

$61 \quad K S S S$ 2, 50, h. 92.

62 Yıldız, "Aykırı Vakıflar”, 143.

63 Vakıf listesi için bk. Yıldız, "Aykırı Vakıflar", 157-158.

64 KSSS 46, 76, h. 108.

65 KȘS 44, 46, H. 67.

66 Arz; arâzi kelimesinin tekilidir. Mehmet Zeki Pakalın, Osmanlı Tarih Deyimleri ve Terimleri Sözlüğü (Millî Eğitim Bakanlı̆̆ı Yayınları, 1993), 1/65. 
ettiğini iddia etmektedir. Fakat Pavlo Kilise mütevelliliğinden azledilince davacının deyişiyle çirkefe yatıp mezkûr tarlanın kendisi tarafından Avraşim isimli zimmîden 600 akçeye satın alındığını ve kendisinin vakfettiğini fakat mütevelliye teslim etmediği için mülkünün kendisine iade edilmesini istemiştir. Ancak Lefkoşa kadısı Mevlânâ Abdülhalimzâde Ali Efendi huzurunda Ramazan bin Abdurrahman ve Muharrem isimli müslim şahısların şehadetleri ile tarlanın Avraşim isimli zimmî tarafından kiliseye vakfedildiği ispatlanınca tarlanın, Kilise adına mütevelli Mihail veledi Kostantin'e iadesine karar verilir.67 Fakat Zorzi'nin bu süreçte vefat etmesi üzerine kızı 1043 yılına ait bir hüccet ile tarlaya yine el koyup vermek istememesi üzerine tekrar 1046 yllında mahkemeye başvuran mezkûr kilise mütevellisi yeniden tarlanın Avraşim isimli zimmî tarafından vakfedildiğini kadı huzurunda şahitlerin şehadeti ile ispatlamıștır. Yapılan tahkikatta, Pavlo veledi Zorzi'nin kızı Milo'nun elindeki hüccet geçersiz sayılırken vâkıf Avraşim'in tarlasını hukuka uygun şekilde vakfetmediği görüldüğünden vakfı iptal etmişlerdir. Normalde mevkuf, vakıf hükmünü gerçekleștirmediğinde vâkıfa ya da mirasçılarına mülk olarak geri verilmesi gerekirken Avraşim isimli zimmînin vefat etmiş olması ve varislerinin bulunmaması üzerine toprak İnehoryo köyü sipahilerinden Hacı Hüseyin bin Mehmed, Musa bin Mehmed ve Hacı İbrahim bin Mahmud'a teslim edilmektedir.68 Burada davacıların ifadelerinden anlaşıldığı kadarıyla vâkıf mülkünü vakfederken kilise fukarasına değil bizzat kilisenin şahsına vakfetmiştir. Kiliselere vakıf kurmanın hukuki açıdan geçersiz olma nedenlerini yukarıda zikrettiğimiz üzere mezkûr vakıf da vakfiyeti kadı tarafından onaylanmış olsa bile iptal edilmesi gerektiği verilen fetvalarla sabittir.69

\subsection{Kilise Vakıfları}

Yukarıda vâkıfı belli olan gayrimüslim vakıfları yanında vakfiyesi elimizde olmayıp kilise mütevellileri tarafından idare ve istifade edilen vakıflar da mevcuttu. Tablo 2'de Kıbrıs Şer'iyye Sicillerinde tespit ettiğimiz yirmi bir vakıf kaydının hangi kilise/ manastıra ait olduğu yanında kiliselerin nerede ve hangi cemaate bağlı olduğu bilgileri yer almaktadır. Tablo 2'de verilen kayıt tarihleri vakfın kuruluş tarihi değil sicildeki kayıt tarihidir.

Tablo 2: Kilise Vakıfları

\begin{tabular}{|c|c|c|c|c|}
\hline Sayı & Kilise/ Manastır Adı & Kaza/ Köy & Dini Grup & Kayıt Tarihi \\
\hline 1 & $\begin{array}{l}\text { Analyonda/ Analionda } \\
\text { Manastiri }^{70}\end{array}$ & \begin{tabular}{lr}
\multicolumn{2}{l}{ Lefkoşa'ya bağlı bir } \\
köy olup antik \\
Tamassus \\
bölgesinde \\
almaktadır. & \\
\end{tabular} & Rum & 1 Safer 1058 \\
\hline 2 & $\begin{array}{l}\text { Archangel Michael } \\
\text { Trypiotis Kilisesi }{ }^{71}\end{array}$ & $\begin{array}{l}\text { Lefkoşa'nın } \\
\text { güneyindeki D'Avila } \\
\text { burcu gerisindeki } \\
\text { Tripiotis } \\
\text { mahallesinin } \\
\text { kilisesidir. }\end{array}$ & Rum & 2 Şaban 1110 \\
\hline 3 & $\begin{array}{l}\text { Panagia (Meryemana) } \\
\text { Chryssalaktousa Kilisesi }^{72}\end{array}$ & $\begin{array}{ll}\text { Lefkoşa/ } & \text { Merika } \\
\text { (Dağ) köyü } & \end{array}$ & Rum & 29 Receb 1045 \\
\hline 4 & $\begin{array}{lrr}\text { Neo } & \text { Horio'daki } & \text { Agios } \\
\text { Nikolaos Kilisesi } & \\
\end{array}$ & $\begin{array}{l}\text { Lefkoşa/ } \\
\text { Minareliköy }\end{array}$ & Rum & 1 Receb 1046 \\
\hline 5 & $\begin{array}{l}\text { Ayatodori köyü Kilisesi } \\
\text { (Agios Theodoros (Aziz } \\
\text { Teodoros)) })^{74}\end{array}$ & Mesarya & Rum & $\begin{array}{l}9 \quad \text { Cemaziyelahir } \\
1129\end{array}$ \\
\hline
\end{tabular}

$67 K S S S 4,112$, h. 261.

68 KȘS 4, s. 185, h. 436

69 "Su'al: Zeyd-i zimmî, bir kilisenin rahiblerine ba'zı emlâkini vakf eylese, tescil ettikten sonra mürd oldukta, veresesi kabul etmemeğe kadir olur mu? Cevap: Tamam sıhhat üzerine tescîl-i şer'î oldu ise olmazlar. Kiliseye ise olurlar." Düzdağ, Fetvalar: Ebusuud Efendi, 113.

$70 \quad K S S S$ 1-B, 47, h. 73.

71 KŞS 4, 131 h, 307; KŞS 6, 59, h. 179.

$72 K S S S$, 132, h. 310.

$73 K S S S$ 4, 185 h, 436.

$74 K S S S$ 9, 13, h. 32. 
Osmanlı Kıbrıs'ında Gayrimüslim ve Kilise Vakıfları

\begin{tabular}{|c|c|c|c|c|}
\hline 6 & Aya Brașuki Kilisesi75 & Lefkoşa & Rum & 10 Receb 1133 \\
\hline 7 & $\begin{array}{ll}\text { Ermeni } & \text { (Surp } \\
\text { Asdvadzadzin) Kilisesi }{ }^{76}\end{array}$ & $\begin{array}{l}\text { Lefkoşa Ermeni/ } \\
\text { Arabahmed } \\
\text { Mahallesi }\end{array}$ & Ermeni & 14 Şevval 1134 \\
\hline 8 & $\begin{array}{lcc}\text { Kafesli } & \text { Kilise/ } & \text { Ayios } \\
\text { Kassianos } & \text { Kilisesi77 } & \end{array}$ & $\begin{array}{lr}\text { Lefkoşa } & \text { Kafesli } \\
\text { Mahallesi } & \text { Mağusa } \\
\text { Kapısı yanı } & \\
\end{array}$ & Rum & 12 Muharrem 1135 \\
\hline 9 & $\begin{array}{l}\text { Panagia } \quad(\text { Meryem) } \\
\text { Faneromeni Kilisesi78 }\end{array}$ & $\begin{array}{l}\text { Lefkoşa Yahyabey } \\
\text { Mahallesi/ Banaya } \\
\text { Faneromeni } \\
\text { Mahallesi }\end{array}$ & Rum & 5 Receb 1135 \\
\hline 10 & $\begin{array}{ll}\text { Panagia } & \text { Katharon } \\
\text { Manastırl }^{79} & \end{array}$ & $\begin{array}{l}\text { Girne/ Larnaka } \\
\text { Köyü/ Kozanköy }\end{array}$ & Rum & $\begin{array}{l}21 \text { Cemaziyelevvel } \\
1137\end{array}$ \\
\hline 11 & $\begin{array}{l}\text { Sourp Magar Ermeni } \\
\text { Manastırı/ Alevkayası } \\
\text { Ermeni Manstırı/ Sergis } \\
\text { kilise/ Mağara Manastırı }\end{array}$ & Girne & Ermeni & 17 Ramazan 1137 \\
\hline 12 & $\begin{array}{l}\text { Panagia Chrysaliniotissa } \\
\text { Kilisesi } 81\end{array}$ & $\begin{array}{l}\text { Lefkoşa'nın } \\
\text { İlyonesse Mahallesi }\end{array}$ & Rum & $\begin{array}{ll}16 & \text { Rebiulevvel } \\
1150 & \end{array}$ \\
\hline 13 & $\begin{array}{l}\text { Meryem Ana } \\
\text { Manastırl }^{82}\end{array}$ & $\begin{array}{l}\text { Maratasa Vaadisi } \\
\text { Trodos Dağları }\end{array}$ & Rum & $\begin{array}{l}4 \quad \text { Cemaziyelevvel } \\
1200\end{array}$ \\
\hline 14 & Aziz Lazaros Kilisesi ${ }^{83}$ & Larnaka & Rum & 13 Zilhicce 1223 \\
\hline 15 & $\begin{array}{l}\text { Hursopolid } \\
\text { (Chrysosotiros) Kilisesi }{ }^{84}\end{array}$ & Larnaka & Rum & 13 Zilhicce 1223 \\
\hline 16 & Ayapareskevi Manastırı 85 & $\begin{array}{l}\text { Girne } \quad \text { Vasilya/ } \\
\text { Vasilia/ Karşıyaka }\end{array}$ & $\begin{array}{l}\text { Tûr-i Sînâ } \\
\text { Mastırına } \\
\text { bağlı }\end{array}$ & 29 Receb 1256 \\
\hline 17 & $\begin{array}{l}\text { Eleusa Manastırı (Panagia } \\
\text { Eleusa Manastırı / } \\
\text { Kutsanmış } \\
\text { Eleousa Manastırı) }\end{array}$ & $\begin{array}{ll}\text { Karpaz } & \text { Kazası/ } \\
\text { Dipkarpaz } & \end{array}$ & $\begin{array}{l}\text { Tûr-i Sînâ } \\
\text { Mastırına } \\
\text { bağlı }\end{array}$ & 29 Receb 1256 \\
\hline 18 & $\begin{array}{l}\text { Ayios Porpos (Azize } \\
\text { Catherine) Kilisesi87 }\end{array}$ & Baf Kukla Köyü & $\begin{array}{l}\text { Tûr-i Sînâ } \\
\text { Mastırına } \\
\text { bağlı }\end{array}$ & 29 Receb 1256 \\
\hline 19 & Aya Orsbitis Kilisesi88 & Hirsofi & $\begin{array}{l}\text { Tûr-i Sînâ } \\
\text { Mastırına } \\
\text { bağlı }\end{array}$ & 29 Receb 1256 \\
\hline 20 & Ayiosyani Manastırı ${ }^{89}$ & $?$ & $\begin{array}{l}\text { Kudüs Rum } \\
\text { Patriğine } \\
\text { bağll }\end{array}$ & 16 Ramazan 1252 \\
\hline 21 & Ayayorgi Manastırı ${ }^{90}$ & Omorfa/ Güzelyurt & $\begin{array}{l}\text { Kudüs Rum } \\
\text { Patriğine } \\
\text { bağll }\end{array}$ & 29 Receb 1137 \\
\hline
\end{tabular}

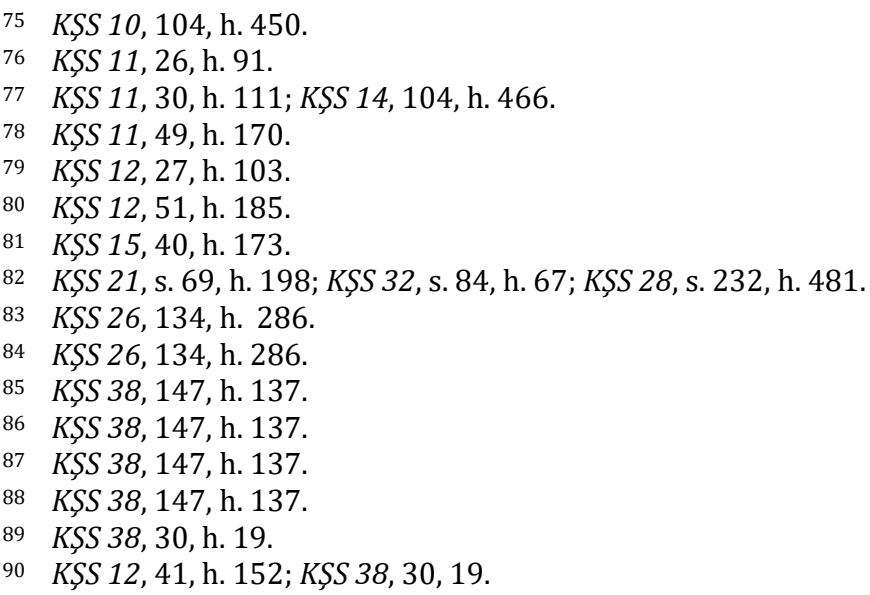


Osmanlı Devleti'nde Ortodoks Rum Kiliselerinin durumu özellikle Fatih Sultan Mehmed'in İstanbul'u fethinden sonra kiliseyi ihyası ve onlara verilen haklar bağlamında iyileșerek devam etmekteydi. Bu durumun istisnası kilise vakıflarında belli kısıtlamalara gidilen II. Selim ve Ebussuûd dönemidir. Toprakların genişlemesiyle birlikte sayıları da değişen Rum Ortodokslarına ait kiliselerin merkezleri İstanbul, Antakya, Kudüs ve İskenderiye olmak üzere dört Patrik'ten oluşmaktaydı. Bu Patriklere bağlı olarak da seksen sekiz metropolit mevcuttu. 1804 yılında yukarıda saydığımız dört Rum Patrik altında Tûr-i Sînâ ve Kıbrıs Başpiskoposlukları yanında otuz üç piskoposluk ile doksan altı metropolit bulunuyordu. ${ }^{91}$ Osmanlı coğrafyasında bu patriklerin kontrolünde olan kiliselerin sınırları kesin çizgilerle çizilmemişti. Birbirine yakın yerlerde birden fazla patriğe bağlı kilise bulunabilmekteydi. Nitekim Tablo II'de görüldüğü üzere Kıbrıs gibi küçük olarak nitelendirilebilecek bir coğrafyada bile vakıflara sahip Rum Ortodoks Başpiskoposluğuna bağlı en az on dört, Kıbrıs Ermeni Bașpiskoposluğuna bağlı iki, Tûr-i Sînâ Başpiskoposluğuna bağlı dört ve Kudüs Rum Patrikliğine bağlı iki kilise ve manastır bulunmaktadır.

Kıbrıs'ta bulunan kiliseler hakkında yeri geldikçe bilgiler verilerek Ada üzerindeki vakıflarına değinilecektir. Adadaki Kudüs Rum Patrikliği ve Tûr-i Sînâ Manastırına ait kiliseler ve sahip oldukları mülk ve vakıflar hakkında Kıbrıs şer'î sicillerinde birkaç berat bulunmaktadır. Kıbrıs ile ilgili araştırmalarda da bu iki kiliseyle ilgili pek bilgiye rastlanmadığı görülmektedir.

Osmanlı topraklarında bulunan patrikliklerden en eskisi ve en yüksek statülü olanı Kudüs Rum Ortodoks Patrikliği'dir. ${ }^{92}$ Bu patrikliğe bağlı Tûr-i Sînâ'da bulunan ve Hristiyanlarca kutsal sayılan Azize Catherina ${ }^{93}$ Manastırı bir diğer önemli mabetlerdendir.94 Bu iki kiliseye ait beratlarda önemli bir nokta dikkat çekmektedir. Patrikliğe ve manastıra bağlı Ada'da bulunan kiliselerin Hz. Peygamber ve Hulefâ-yi Râşidîn zamanından beri daha sonraki hükümdarlarla da devam eden süreçte kendilerine haklar verilerek her türlü vergiden muaf tutulduklarından ve vakıflara sahip olduklarından yerel yöneticiler İstanbul'dan mezkûr kiliselerin hakları hatırlatılarak buralara kimsenin müdahale etmemesi konusunda uyarılmaktadırlar. ${ }^{95}$

Kudüs 638 yılında Hz. Ömer döneminde Müslümanlar tarafından fethedildi. Bizans yönetiminden Müslümanların kontrolüne geçen bu topraklarda bulunan kiliseler özellikle de Kudüs Rum Patriği Sophronios, Hz. Ömer'i karşılamış ve halife tarafından İslam tarihinde ilk defa patrikliğin statüsünü tanıyan ve gayrimüslimlere geniş haklar veren berat Patriğe sunulmuştur. $\mathrm{Bu}$ berat korunarak aynı haklar diğer Müslüman hükümdarlarla birlikte Osmanlı'nın Filistin ve Mısır'ı Yavuz Sultan Selim tarafından alınmasından önce Fatih Sultan Mehmed tarafından korunarak devam ettirilmiştir. ${ }^{96}$ Yavuz Sultan Selim 1516 yılında Kudüs'ü aldığında kendisinden önce yapılan ahitnameleri devam ettirmiştir. Daha sonra gelen padişah Kanuni Sultan Süleyman ve diğerlerinin de benzer fermanlarla bu hak ve hürriyetlerin devamlılığını sağladığı görülmektedir. ${ }^{97}$

Konumuz dışında kaldığından ayrıntılarına girmeyeceğimiz bir durum Tûr-i Sînâ Manastırı'nda bulunan ve müsteşrikler tarafından da yayımlanan bir beratta Hz. Muhammed (sav)'in henüz kendisine peygamberlik gelmediği dönemde bu kiliseyi ziyaret ettiği ve burada kaldığı, peygamberlik geldikten sonra da kilise keşişleri tarafından Medine'de ziyaret edildiği ve kendisinin imzasıyla kendilerine haklar verildiği iddiasıdır. Gerek İslam tarihi kaynaklarında böyle bir rivayetin bulunmaması gerekse de Osmanlı'nın bu coğrafyayı almasından sonra mezkûr kiliselerin ellerinde bulunan beratların Yavuz Sultan Selim tarafından ücret

91 M. Macit Kenanoğlu, Osmanlı Millet Sistemi: Mit ve Gerçek (İstanbul: Klasik Yayınları, 2017), 175-176.

92 İhsan Satış-Muhammed Ceyhan, "Kudüs Rum Patrikhanesi”, Belleten 79/285 (01 Ağustos 2015), 676.

93 Azize Katerina ve Kıbrıs ile bağlantısı hakkında bk. Ata Atun, "Tarihin Derinliklerinde Kaybolmuş Kıbrıs'lı Azize Katerina", Folklor Edebiyat Dergisi 9/35 (ts.), 175-179.

94 Magda H. Ohnefalsch Richter, Greek Customs and Mores in Cyprus (Nicosia: Laiki Group Cultural Centre Publicasion, 2006), 71-72.

$95 K S S S 38,189$, h. 212.

96 Satış- Ceyhan, "Kudüs Rum Patrikhanesi”, 678-684.

97 Satış-Ceyhan, "Kudüs Rum Patrikhanesi", 684. 
mukabilinde bir kopyası kendilerinde bırakılarak orijinal beratların İstanbul'a getirtilmesi ve de mezkûr beratın Hz. Muhammed'e (s.a.v) değil de Hz. Ömer'e ait olması bu iddiayı zayıflatmaktadır. 98

Hulefâ-yi Râşidîn döneminden beri süregelen bahsettiğimiz dokunulmazlığın Osmanlı'da da devam ettiği şu örnek üzerinden açıkça görülebilir. Kudüs Rum Ortodoks Patriğine bağlı Kıbrıs'ta bulunan Ayiosyani ve Ayiosyorgi Manastırlarına ait zeytin ağaçları ve diğer emlaktan usule aykırı olarak öșür istendiğinde Patrik Atanasyus'un İstanbul'a gerekli șikayetleri yapması üzerine İstanbul'dan Kıbrıs Muhassılı ve nâibine hitaben yazılan 1250/1835 yılına ait emirde Patrik Atanasyus'un elinde bulunan berat ve Hazine-i Âmirede bulunan Piskopos Mukâtaası defterleri incelenmiştir. Bu inceleme sonucunda patrikliğe bağlı yerlerde bulunan manastır ve kiliselere ait bağ, bahçe, çiftlik, panayır, ağaç vs. mülklerine eskiden olduğu gibi dışarıdan müdahale edilmeyip idarelerine bırakılmıştır. Bu müdahale Divân-ı Hümayun tarafından verilen şu cevapla önlenmiștir: "...kiliselerine müte'allık bağ ve bağçe ve çiftlik ve değirmen ve tarla ve çayır ve büyût ve dekâkîn ve eșcâr-ı müsmire ve gayr-i müsmirelerine ve ayazma ve manastırlarına ve sâ'ir bunun emsâli kiliseye vakf olan eșyâ ve davarlarına bundan evvel Kudsi şerîf patriği olanlar ne vechile zapt ve tasarruf edegelmişler ise patrik-i lâhik-i mersûm dahi ol vechile zapt ve tasarruf eyleyüp hilâf-ı şürût ve mugâyir-i emr-i âlî-şân kimesne tarafından bîvech müdâhale ve ta'arruz etdirmeyesiz, şöyle bilesiz, alâmet-i şerîfe i'timâd kılasız." 99

Kıbrıs Șer'iyye Sicilleri'nde bulunan üç kayıttan anlașllyyor ki Ada'da Tûr-i Sînâ Manastırı'na bağlı dört manastıra ait mülkler ve vakıflar bulunmaktadır. Yine İstanbul'a yapılan bir şikâyete binaen Kıbrıs Muhassılı Osman'a hitaben yazılan emirde, Ada'daki Tûr-i Sînâ manastırlarında bulunan ruhban fukarasının, insanların hür iradeleri ile kendilerine bağışladıkları vakıfları dışında bir gelirleri olmadığı zikredilirken Girne'nin Vasilya/ Vasilia/ Karşıyaka köyünde bulunan Ayapareskevi, Karpaz kazası/ Dipkarpaz'da Eleusa (Panagia Eleusa / Kutsanmış Meryem Eleousa Manastırı), Baf'ın Kukla Köyü Ayios Porpos (Azize Catherine) ve Hirsofi'de Aya Orsbitis Manastırlarının isimleri verilmektedir. Mezkur belgede;“...kadîmden mevkûf ve müsakkafâtlarından mugâyir-i şürût ba'zı mütâlebât-ı muhdese ile ta'addî ve rencîde olunduğu..."100 şikayet sebebinden bahsedildikten sonra Tûr-i Sînâ Manastırına bağlı Manastır ve kiliselerine "Resûl-i Ekrem aleyhi's-selâm ve hulefâ-yı izâm hazerâtı cânib-i sa'âdet-menâkıbları tarafından ihsân buyurulan ahidnâme-i hümâyûn mazmûn-ı merhamet-makrûnu üzre selâtîn-i mâziyye taraflarından yedlerine verilen ahidnâme-i șerîfe ve berevât ve evâmir-i münîfe mûceblerince..."101 sahip oldukları vakıf, mülk, değirmen, dükkanlarından ve limanlardan geçişte vergi alınmadığı, eskiden olduğu gibi beratlarının yenilendiği ve bu bağlamda yapılan tacizlerin engellenmesi istenmektedir.

Yukarıda zikrettiğimiz gibi kiliselerin adına vakıf kurulamadığından gayrimüslim şahıslar da kilise rahipleri adına vakıf kurmakta ve vakıf mülkleri deftere kaydedildiği şekilde rahibin vefatından sonra gelen rahibe geçmekteydi. Fakat bu durum kilise ve varisler arasında bazı anlaşmazlıklara neden olmaktaydı. Mesela Tûr-i Sînâ'ya bağlı Vasilya köyündeki Ayapraşkova Manastırı'nda vefat eden rahip Grigoryos'un terekesinde bulunan manastıra ait mülklerin varisleri tarafından istenmesi üzerine Başpiskoposun başvurusu dikkate alınarak kiliseye ait mevkuf çıkarıldıktan sonra geri kalanı varisler arasında bölüştürülmüştür. Buradan anlıyoruz ki Ebussuûd Efendi'nin fetvasına binaen Ada'daki kilise vakıfları da ruhban sınıf adına kaydedilmiştir. ${ }^{102}$

Ada'da bulunan Tûr-i Sînâ Manastırına ait mülklerin yanında burada yaşayan insanlar ve tarım yapmak için ihtiyaç duyulan suyun karşılanması için vakfa ait su yollarının yapıldığı anlaşılmaktadır. Girne'de Korno Dağı'nın nihayeti denilen mevkiden ve Ayavasili denilen

98 Gerekli iddia ve tartışmalar için bk. İsmail Hakkı Göksoy, "Hz. Peygamber'in Bazı Hıristiyan Topluluklara Verdiği Kabul Edilen Ahidnamelerle İlgili İngilizce Bir Kitap", Süleyman Demirel Üniversitesi İlahiyat Fakültesi Dergisi 33 (01 Aralık 2014), 249-258; Internet Haber, "İște Patriğin Söylediği O Mektup”, (Erişim 23 Aralık 2009); Muhammed Hamidullah, el-Vesaiku's-siyasiyye:Hz. Peygamber Döneminin Siyasi-İdari Belgeleri. (İstanbul: Kitabevi) (Erișim 29 Mart 2021).

$99 \quad K S S S 38,30$, h. 19.

100 KSSS 38, 147, h. 137.

101 KSSS 38, 147, h. 137.

$102 K S S 38,189$, h. 212. 
mevkilerde yapılan su yolları sayesinde akıtılan Ayapraşkova Manastırı vakfına ait tatlı suların adanın Osmanlı tarafından fethinden önce ve sonrasında manastırın kontrolünde olduğu belirtilmiștir. Manastır vakfına ait mezkûr tatlı sulara gerek yönetici gerekse de halktan kişilerin müdahalesi üzerine İstanbul'a yapılan şikâyet ve İstanbul'dan Kıbrıs muhassılı Mehmed Emin Efendi'ye yazılan uyarı yazısı ile yapılan taciz engellenmiştir.103

Kıbrıs'ta Tûr-i Sînâ Manastırına ait 4 manastırdan 1894-1912 yılları arasında yalnızca Vasilya Ayapraşkova Manastırı ile Dipkarpaz'ın batısındaki Eleusa Manastırı aktifti. Bu manastırlara eskiden olduğu gibi 2 yıllığına Tûr-i Sînâ Manastırından gönderilen keşişler, manastırlara ait bağ, bahçe ve tarlaların işletilmesi, ürünlerin hasat edilmesiyle ilgilenmekteydiler. Günümüzde harap durumda olan iki manastıra ait su yolları mevcudiyetini korumaktadır.104

Ada'da vakıflara sahip bir diğer gayrimüslim grup ise Ermenilerdi. Osmanll, Ada'yı aldığında Kıbrıs'ta çok fazla sayıda Ermeni bulunmamakla beraber dağınık olarak bulunan cemaat üyeleri sonraki dönemde genel olarak Lefkoşa'da toplandılar ve devlet tarafından kendilerine kiliseler verildi. Tarihi süreçte farklı Piskoposluklara bağlı olan Ermeniler ulaştığımız belgelerde görüldüğü kadarıyla İstanbul Ermeni Patrik'ine bağlı olup Patrik'in önerisi ve hükümetin verdiği berat ile gönderilen Marhasalar tarafından idare edilmişlerdir. Ada'da Lefkoşa Karamanzâde Mahallesinde bulunan bir kilise Osmanlı döneminde ilk başlarda tuz ambarı olarak kullanılırken Ermeni cemaati ileri gelenlerinin buranın kendilerine verilmesi hususunda II. Selim'e yazdıkları bir yazı sonucunda Kıbrıs Beylerbeyi Muzaffer Paşa'ya kilisenin ibadet etmeleri amacıyla Ermenilere verilmesine dair bir emir yazılmıştır. 105 Mezkûr cemaate ait bir diğer kilise ise Girne'de Sourp Magar, Sourp Magar Ermeni Manastırı, Magaravank, Alevkayası Ermeni Manastırı, Ayios Makarios Manastırı, Kutsanmış Aziz Makarios Manastırı gibi farklı adlarla anılan manastırdır.106 İstanbul Ermeni Patrik'i Agop döneminde Kıbrıs Marhasası seçilen Rahip Avadik'e verilen berat incelendiğinde diğer kilise yetkililerine benzer yetkiler verildiği görülmektedir: "ve kadîmden kendü âyînleri üzre kiliselerine müte'allik bağ ve bağçe ve çiftlik ve değirmen ve ayazma ve tarlalarına ve manastırlarına ve büyût ve dekâkin ve sâir bunun emsâli kenîselerine vakf olan eşya ve davarlarına bundan evvel marhasa olanlar ne vech ile zabt ve mutasarrıf ola gelmişler ise, mesfûr Avadik nâm râhib dahi ol-minvâl üzre zabt u tasarruf eyleyüp..."107 Beratta geçtiği șekliyle marhasanın Ermeni cemaati ile ilgili yetkileri geniş olarak sayılırken bizim konumuz ile ilgili kısımda da açıkça ifade edildiği gibi kiliseye ait vakıflar da marhasaların kontrolüne verilmiştir. Marhasalar vakıflara mütevelliler atayarak yeni vakfedilen mevkufu teslim ve idare etmiştir. Atadığı mütevelliler de elde bulunan vakfa ait paralar ile kilise vakfı adına yeni akarât satın almışlardı. Lefkoşa'nın Karamanzâde mahallesinde sâkin Ermeni cemaatinden Avakim veled-i Sarkiz aynı mahallede bulunan ev ve eve ait bahçe ile sulama hakkını aynı mahallede bulunan Ermeni Kilisesi adına kilise mütevellisi Hagi Bogos veled-i Avraim'e 1231/1816 yllında 18000 kuruşa satılmıştır. 108

Gayrimüslim kiliselere ait vakıflar hakkında elimizde toplu bir kaynak olmadığından bilgilere, dağınık olarak bulunan arşiv kayıtları içerisinde rastlamaktayız. Kayıtlarda geçen bazı bilgiler doğrudan kilise vakıfları ile ilgili olurken bazı bilgiler ise başka işlemlerle ile ilgili olup içerisinde kilise vakıf mülklerinden dolaylı olarak bahsedilmiştir. Örneğin Lefkoşa Karamanzâde mahallesinde 1134/1722 tarihli bir mülk satış işleminde satılan mülkün yeri tarif edilirken bir taraftan Ermeni Kilisesi Vakfı olan dükkân ile bitişik olduğu zikredilmektedir. ${ }^{109}$ Bir diğer belge ise Girne'deki Ermeni Manastırı'na ait vakıf bahçelerde çalışan bahçıvan Lino bint-i Marko ve

103 KSSS 27, 28, h. 78.

104 Richter, Greek Customs and Mores in Cyprus, 71-72.

105 Osmanlı'nın Kıbrıs'ta Ermeni cemaatine verdiği dinî haklar için bk. Gazioğlu, "Kıbrıs'ta Türk Yönetiminin Hoşgörülü Davranıșı ve Hristiyan Toplumlara Tanınan Haklar", 225-227; Zekai Altan, Gizemli Kıbrıs (Lefkoşa: Cinius Yayınları, 2016), 354-355.

106 Çalışmamızda kullandığımız kilise ve manastırlar hakkında değerli bilgilerinden faydalandığımız Kıbrıshı arkeolog Tuncer Bağışkan’a müteşekkiriz. Tuncer Bağışkan, "Kıbrıs Tarihinde Ermeniler”, Adres Kıbrıs Dergisi 133 (29 Kasim 2013), 32-33.

$107 K S S S 16,29$, h. 49.

108 KSSS 29, 68, h. 125.

109 KŞS 11, 26, h. 91. 
kızı Zonya'ya meçhul bir şahıs tarafından yapılan saldırı ile alakalı 1137/1725 tarihli mahkeme kaydıdır. 110

Kıbrıs'taki son gayrimüslim grup ise Ada'da sayıları ile kilise ve manastırları en fazla olan Rum Ortodoks Bașpiskoposluğudur. Yine bulduğumuz kayıtlarda en fazla vakfa sahip kilise sayısı bu gruba aittir. Yukarıda Rum Ortodoks Kilisesi fukarasına vakfedilmiș ve elimizde vakfiyesi olan yedi vakıf dışında gerek satış gerekse de başka konularda şer'iyye sicillerine konu olan dâvalarda söz edilmiș vakfa sahip en az on iki kilise ve manastır mevcuttur.

Kiliselerin vakfı başpiskopos tarafından atanan rahip ya da mütevelli tarafından idare edilmiştir. Mütevellilerin vakıf hakkında yaptıkları işlemler kadı tarafından takip ve kontrol edilmekteydi. Lefkoşa'nın Analyonda/ Analionda Manastırı'na ait aynı köydeki boş arazinin ve elli kök zeytin ağacının vakfa fayda sağlamadığı, buranın Assimo veled-i Tomassin isimli zimmîye 2000 akçeye satılarak bunun yerine vakfa yarar sağlayacak bir bahçe satın almanın daha uygun olduğu görüşü kadıya sunulmuş ve şahitler huzurunda uygun bulunarak mevkûfat satılmıștır. ${ }^{111}$ Bunun tam tersi mütevellilerin vakfa mülk satın aldığı da görülmüștür. Lefkoșa'nın Bodamya köyünde bulunan Archangel Michael Trypiotis Kilisesi vakfının 1110/1699 yllında mütevellisi olan İstefani veled-i İstefani on üç kök zeytin ağacını vakıf adına Filori ve Mihail isimli zimmîlerden on esedî kuruşa satın almıştır.112 Yine aynı şekilde Lefkoşa'ya bağlı Paliometocho adıyla bilinen köyde bulunan Panagia (Meryemana) Chryssalaktousa kilisesi için Elisava bint-i Paskali isimli zimmîye ait Serez köyünde bulunan altı dönüm bağ ile şırahâne olan üç küplük yerini kilise mütevellileri Valyandi veled-i Kostantin, Çiryako veled-i Yani ve Vodvizo veled-i Petro'ya 1680 akçeye satın almışlar. ${ }^{113}$

Müslümanlar tarafından oluşturulan vakıflara ait akârâtın gayrimüslimlere kiraya verildiği görüldüğü gibi bunun tam tersi de mümkündü. Lefkoşa'da ticaretin yoğun olarak yapıldığı çarşılarda kilise fukarası için bağışlanmış ya da ticaret için kilise tarafından satın alınıp vakfa bağışlanmış dükkanlar bulunmaktaydı. Bunlardan bir tanesi olan 1045/1635 yllında II. Selim vakıf akârâtından Bedesten kapısı içerisinde Tribyodi Kilisesi vakfına ait bir dükkân, aylık 31 akçeye olmak üzere on yıllı̆̆ına Müslüman ahaliden Terzi Ali bin Abdullah'a kiralanmıștır. On dört ay geçtikten sonra vakıf mütevellisi Marat veled-i İmirşah'ın kiracıyı haksız yere dükkândan çıkarmak istemesi üzerine kiracı kadıya başvurmuş ve mahkeme mütevelliyi haksız bularak kiracı lehine karar vermiştir.114

Kadı huzurunda sonuca bağlanan diğer davalar ise Girne/ Larnaka Köyü/ Kozanköy'de bulunan Panagia Katharon Manastırı115 ile Lefkoşa'da Kafesli Mahallesinde bulunan Ayios Kassianos Kiliseleri116 hakkındadır.

Kiliselerin tamir ve tadilatları izne tâbi olmakla birlikte müsakkafâtı için çıkan masraflar kiliselerin bütçesinden karşılanmaktaydı. Bütçenin yetmediği durumlarda vakıf mülklerinin satıldığı görülmektedir. Lefkoşa'da Chrysaliniotissa/ İlyonesse Mahallesinde bulunan Panagia Chrysaliniotissa Kilisesi müsakkafâtı topraktan bina edildiği için harap duruma geldiği ve acilen tamir edilmesi gerektiğini mahkeme huzurunda dile getiren mütevelli Nikola veled-i Luizu elinde bulunan fetvaya binaen vakfa ait olan 6 dönümlük dut bahçesini ve derununda bulunan 3 odalı evi ve su kuyusu dolabı içeren mevkuf bahçeyi satarak müsakkafâtı tamir etmek için kadıdan izin istemektedir. Yapılan inceleme sonucunda vakıf mülkünün tadilata acil muhtaç olduğu göz önünde bulundurularak mütevelliye mevkufun satma yetkisi verilmiştir. Nihayetinde yapılan açık artırmada mülk 500 kuruşa Abdi bin Ali'ye satılmıștır. ${ }^{117} \mathrm{Bu}$ davalardan da açık olarak kâdının Müslüman vakıflarında olduğu gibi gayrimüslim vakıfları üzerindeki nezareti ve son karar verici merci olduğu ortaya çıkmaktadır.

\footnotetext{
$110 K S S S$ 12, 51, h. 185.

$111 K S S$ 1-B, 47, h. 73.

$112 K S S$ 6, 59, h. 176.

113 KSSS 4, 132, h. 310.

$114 K S S 4,131$, h. 307.

$115 K S S$ 12, 27, h. 103.

$116 K S S S 14,104$ h. 466.

117 KSSS 15, 40, h. 173.
} 


\section{Sonuç}

İnsanoğlunun, muhtaç olana yardım etme duygusu ve dinlerin bu duyguyu beslemesinden doğan vakıf birçok millet ve medeniyette görülmektedir. Osmanlı Devleti Kıbrıs adasını almadan önce burada mevcut olan Katolik ve Ortodoks kiliselerinin ve bu kiliselere ait mülk ve vakıflarının olduğu arşiv kayıtlarından anlaşılmaktadır. Özellikle Kıbrıs'ın fethi ve sonraki dönemi kapsayan mühimme defterlerinde, camiye tahvil edilen ya da mülk olarak satılan Katolik kiliselerinin yanı sıra aktifliği devam eden Tûr-i Sînâ Manastırının ve diğer kiliselerin de vakıfları olduğuna dair çok sayıda hüküm bulunmaktadır.

Gayrimüslim vakıfları ile ilgili yetkili merci, diğer vakıflarda olduğu gibi, şerî mahkemelerdir. Gerek vakıfların onaylanması gerekse vakıflarla ilgili ihtilafların giderilmesi bizzat kadı huzurunda yapılmaktadır. Nitekim kadı huzurunda görülen bu işlemler ve İstanbul'dan da Kilise ve vakıflarla ilgili gelen berat, ferman vb. yazıların sicillere kaydedildiği görülmektedir. Yapılan akademik çalışmalarda bir makale dişında genel olarak Müslüman vakıfları üzerinde durulmuş ve Kıbrıs'taki gayrimüslim ve kilise vakıfları ihmal edilmişlerdir. Bu makalemizde Kıbrıs Şer'iyye Sicillerinde yaptığımız araştırma neticesinde daha önce yapılan çalışmada değinilen yedi vakfa ilave olarak dört şahıs vakfı ve yirmi bir kilise vakfı tespit edilip incelenerek tahlil edilmiştir.

Adadaki gayrimüslim vakıfları incelendiğinde bütün cemaatler tarafından vakıfların kurulduğu görülmektedir. Nitekim vakfiyesi elimizde olan on bir vakıftan bir tanesi Yahudi, iki tanesi Ermeni, sekiz tanesi de Rumlar tarafından kurulmuştur. Vakfiyesi elimizde olmayıp yalnızca cemaatleri tarafından fukarası ya da rahiplerinin faydalandığı kiliselerden Rum Ortodoks on dört, Ermeni iki, Tûr-i Sînâ Başpiskoposluğuna bağlı dört ve Kudüs Rum Patrikliğine bağlı iki kilise ve manastır bulunmaktadır. Bunlardan yalnızca bir tanesi Yahudiler tarafından kurulmuş ve mevkuf Yahudi cemaatinin faydasına geliri de başka bir dinin mabedine şart koşulmuştur. Diğer vakıfların hepsi vâkıfın mensubu olduğu dinin fukarasının ya da din görevlilerinin istifadesine sunulmuş ve mütevellilerin de bu kiliselerin mütevellisi olması şart koşulmuştur. Hayri vakıf kurmada Müslümanlarla aynı hak ve sorumluluklara sahip olan gayrimüslimlerin de bu şartlardan bir ya da birkaçını yerine getirmediği zaman kurdukları vakıfların iptal edildiği görülmektedir. 1045 tarihli Avraşim vakfının hukuka uygun olarak kurulmadığı tespit edildiğinden iptal edilmiştir.

\section{Kaynakça}

Akgündüz, Ahmed. İslam Hukukunda ve İslam Tatbikatında Vakıf Müessesesi. İstanbul: Osmanlı Araştırmaları Vakfı, 1. Basım, 1996.

Alasya, Halil Fikret. Kıbrıs Tarihi ve Kıbrıs'da Türk Eserleri. Ankara: Türk Kültürünü Araștırma Enstitüsü, 1977.

Altan, Zekai. Gizemli Kıbrıs. Lefkoşa: Cinius Yayınları, 3. Basım, 2016.

Atun, Ata. "Tarihin Derinliklerinde Kaybolmuş Kıbrıs'lı Azize Katerina”. Folklor Edebiyat Dergisi 9/35 (ts.), 175-179.

Bağışkan, Tuncer. "Kıbrıs Tarihinde Ermeniler”. Adres Kıbrıs Dergisi 133 (29 Kasım 2013), 3233.

Berki, Ali Himmet. Vakıflar. 2 Cilt. İstanbul: Cihan Kitaphanesi, 1940.

Berki, Ali Himmet. "Vakıfların Hukuk, Mahiyeti, İnkişafı ve Tekâmülü, Cemiyet ve Fertlere Sağladığı Faideler". Vakıflar Dergisi 6 (1965), 9-15.

Ceyhan, Muhammed. Osmanlı Devleti'nde Gayrimüslimlerin Mülk ve Vakıf Edinimi (18. yüzyıl). Ankara: Ankara Üniversitesi Sosyal Bilimler Enstitüsü, Doktora Tezi, 2016.

Çiçek, Kemal. “Kıbrıs (Osmanlı Dönemi)”. Türkiye Diyanet Vakfı İslam Ansiklopedisi. 25/374-380. Ankara: TDV Yayınları, 2002.

Demirkent, Işın. "Kıbrıs (Tarih)". Kıbrıs. 25/371-374. Ankara: TDV Yayınları, 2002. https://cdn.islamansiklopedisi.org.tr/dosya/25/C25023420.pdf 
Dündar, Recep. Kıbrıs Beylerbeyliği (1570-1670). Malatya: İnönü Üniversitesi Sosyal Bilimler Enstitüsü, Doktora Tezi, 1998.

Düzdağ, Mehmet Ertuğrul. Fetvalar: Ebusuud Efendi. İstanbul: İ.İ.A Yayınları, 1972.

Erdoğru, M. Akif. “Kıbrıs Ermenileri Üzerine Notlar (1580-1640)”. Tarih İncelemeleri Dergisi 17/1 (01 Haziran 2002), 1-12. https://dergipark.org.tr/tr/pub/egetid/68755

Gazioğlu, Ahmet C. "Kıbrıs'ta Türk Yönetiminin Hoşgörülü Davranışı ve Hristiyan Toplumlara Tanınan Haklar". Kıbrıs'ın Dünü-Bugünü Uluslararası Sempozyumu, Gazi Mağusa, 28 Ekim - 2 Kasım 1991. ed. Güner Göktuğ-Sabahattin İsmail. 215-229. Ankara: Doğu Akdeniz Üniversitesi ve Van Yüzüncü Yıl Üniversitesi Yayınları, 1993.

Göksoy, İsmail Hakkı. "Hz. Peygamber'in Bazı Hıristiyan Topluluklara Verdiği Kabul Edilen Ahidnamelerle İlgili İngilizce Bir Kitap". Süleyman Demirel Üniversitesi İlahiyat Fakültesi Dergisi, 249-258. https://dergipark.org.tr/tr/pub/sduifd/611743

Günay, Hacı Mehmet. "Vakıf”. Türkiye Diyanet Vakfı İslam Ansiklopedisi. 42/475-479. İstanbul: TDV Yayınları, 2012.

Internet Haber. "İşte Patriğin Söylediği 0 Mektup". Erişim 23 Mart 2021. https://www.internethaber.com/iste-patrigin-soyledigi-o-mektup-223231h.htm

Hakeri, Bener Hakkı. Başlangıcından 1878'e Dek Kıbrıs Tarihi. Lefkoşa: Kuzey Kıbrıs Türk Cumhuriyeti Milli Eğitim ve Kültür Bakanlığı, 1993.

Hamidullah, Muhammed. el-Vesaiku's-siyasiyye : Hz. Peygamber Döneminin Siyasi-İdari Belgeleri. İstanbul: $\quad$ Kitabevi $\quad$ Yayınlarl. Erişim $29 \quad$ Mart 2021. http://ktp.isam.org.tr/ktp/recordview.php?idno=178532\&ele=\%3D\&wKitaplar=vesaik \&wYazarlar=muhammed+hamidullah

Hamidullah, Muhammed. İslam'da Devlet İdaresi. çev. Kemal Kuşcu. İstanbul: Beyan Yayınları, 1998.

Hill, George. Kıbrıs Tarihi: Osmanlı ve İngiliz İdaresi Dönemi 1571-1948. çev. Nazım Can Serbest. İstanbul: Türkiye İş Bankası Kültür Yayınları, 2016.

Hüsrev. Gurer ve Dürer. çev. Arif Erkan. 4 Cilt. İstanbul: Eser Neşriyat, 1979. http://ktp.isam.org.tr/ktp/recordview.php?idno=59122\&ele=\%3D\&wYazarlar=arif + erk an

Jennings, Ronald C. Christians and Muslims in Ottoman Cyprus And The Mediterranean World 1571-1640. New York: New York Universty Press, 1993.

Karataş, Ali İhsan. "Osmanlı Devleti'nde Gayrimüslimlere Tanınan Din ve Vicdan Hürriyeti”. Uludağ Üniversitesi İlahiyat Fakültesi Dergisi 15/1 (2006), 267-284.

Kenanoğlu, M. Macit. Osmanlı Millet Sistemi: Mit ve Gerçek. İstanbul: Klasik Yayınları, 4. Basım, 2017.

Kermeli, Eugenia. "Ebû's-Su'ûd'a Göre Kilise Vakıfları Osmanlı Hukukundaki Teori ve Pratiği”. çev. Özcan Özgen. Vakıflar Dergisi 34 (2010), 165-176.

Konan, Belkıs. "Gayrimüslim Osmanlı Vatandaşlarının Hukuki Durumuna İlişsin Bir Değerlendirme". Ankara Üniversitesi Hukuk Fakültesi Dergisi 64/1 (01 Mart 2015), 171194. https://dergipark.org.tr/tr/pub/auhfd/510625

Korkmazer, Sıddık. Lala Mustafa Paşa ve Kıbrıs'taki Vakıfları. Bursa: Uludağ Üniversitesi, Sosyal Bilimler Enstitüsü, Yüksek Lisans tezi, 2014.

Köprülü, Mehmed Fuad. İslam ve Türk Hukuk Tarihi Araștırmaları ve Vakıf Müessesesi. Ankara: Akçă̆ Yayınları, 2005.

Kur'ân-ı Kerîm, ts.

Luke, Harry C. Türk idaresinde Kıbrıs 1571-1878. çev. Ali Çakıroğlu. Lefkoşa: Galeri Kültür Yayınları, 2014. 
Metin, Hüseyin. Kıbrıs Tarihine Toplu Bir Bakış. Lefkoşa: Halkın Sesi Basımevi, 1. Basım, 1959.

Müslim b. el-Haccac. Sahihi Müslim. ed. Muhammed Fuad Abdülbaki. Beyrut: Dâru İhyai'tTüraasi'l Arabi, 1956.

Ostrogorski, Georgije. Bizans Devleti Tarihi. çev. Fikret Işıltan. Ankara: Türk Tarih Kurumu Basımevi, 7. Basım, 2011.

Ömer Hilmi Efendi. Ahkâmü'l-evkaf. İstanbul: Matbâ-i Âmire, 1307.

Öz, Mehmet. "Reâyâ". Türkiye Diyanet Vakfı İslam Ansiklopedisi. 34/490-493. İstanbul: TDV Yayınları, 2007.

Özel, Ahmet. "Gayrimüslim”. Türkiye Diyanet Vakfi İslam Ansiklopedisi. 13/418-427. İstanbul: TDV Yayınları, 1996.

Öztürk, Nazif. Menşei ve Tarihi Gelişimi Açısından Vakıflar. Ankara: Vakıflar Genel Müdürlüğü, 1983.

Pakalın, Mehmet Zeki. Osmanlı Tarih Deyimleri ve Terimleri Sözlüğü. 3 Cilt. Milli Eğitim Bakanlığı Yayınları, 1993.

Richter, Magda H. Ohnefalsch. Greek Customs and Mores in Cyprus. Nicosia: Laiki Group Cultural Centre Publicasion, 2006.

Ruben, Walter. "Budhist Vakıfları Hakkında”. Vakıflar Dergisi 2 (1942), 173-184.

Samani, Hasan. Tanzimat Devrinde Kıbrıs (1839-1878). Ankara: Hacettepe Üniversitesi Sosyal Bilimler Enstitüsü, Doktora, 2006.

Satış, İhsan-Ceyhan, Muhammed. "Kudüs Rum Patrikhanesi". Belleten 79/285 (01 Ağustos 2015), 675-712. https://dergipark.org.tr/tr/pub/ttkbelleten/688472

Şengil, Mustafa. Osmanlı'dan Günümüze Kıbrıs İnanç Tarihi. Konya: Necmettin Erbakan Üniversitesi Sosyal Bilimler Enstitüsü, Doktora Tezi, 2020. https://tez.yok.gov.tr/UlusalTezMerkezi/tezSorguSonucYeni.jsp

Tamçelik, Soyalp-Kasapoğlu, Mustafa Kemal. "Kıbrıs'ta Kurulan Gayrımüslim Vakıfları ve Özellikleri (non-Muslim Foundations constituted İn cyprus And Their characteristics)". Osmanlı Dönemi Kıbrıs Vakıfları. 279-338. Lefkoşa: Yakın Doğu Üniversitesi Yayınları, 2017.

Yediyıldız, Bahaeddin. XVIII. Yüzyılda Türkiye'de Vakıf Müessesesi Bir Sosyal Tarih İncelemesi. Ankara: Türk Tarih Kurumu, 2003.

Yıldız, Kenan. "Aykırı Vakıflar: Osmanlıda Fukarâ-yı Müslimîni de Gözeten Gayrimüslim Vakufları". Osmanlı Araștırmaları 54 (21 Haziran 2019), 141-198.

BOA, Osmanlı Arşivi. 12 Numaralı Muhimme Defteri [A.DVNSMHM]. No. 12.

BOA, Osmanlı Arşivi. 16 Numaralı Mühimme Defteri [A.(DVNSMHM)]. No. 16.

BOA, Osmanlı Arşivi. 31 Numaralı Mühimme Defteri [A.(DVNSMHM)]. No. 31.

BOA, Osmanlı Arşivi. Irâde-Hariciye [İ.HR]. No. 142, Gömlek No. 7480.

Kıbrıs Şer'îye Sicil Defteri. KKTC Millî Arşiv, No. 1-A

Kıbrıs Şer'îye Sicil Defteri. KKTC Millî Arşiv, No. 1-B.

Kıbrıs Şer'îye Sicil Defteri. KKTC Millî Arşiv, No. 2.

Kıbrıs Şer'îye Sicil Defteri. KKTC Millî Arşiv, No. 4.

Kıbrıs Şer'îye Sicil Defteri. KKTC Millî Arşiv, No. 6.

Kıbrıs Şer'îye Sicil Defteri. KKTC Millî Arşiv, No. 9.

Kıbrıs Șer'îye Sicil Defteri. KKTC Millî Arşiv, No. 10. 
Kıbrıs Şer'îye Sicil Defteri. KKTC Millî Arşiv, No. 11. Kıbrıs Şer'îye Sicil Defteri. KKTC Millî Arşiv, No. 12. Kıbrıs Şer'îye Sicil Defteri. KKTC Millî Arşiv, No. 14. Kıbrıs Şer'îye Sicil Defteri. KKTC Millî Arşiv, No. 15. Kıbrıs Şer'îye Sicil Defteri. KKTC Millî Arşiv, No. 16. Kıbrıs Şer'îye Sicil Defteri. KKTC Millî Arşiv, No. 21. Kıbrıs Şer'îye Sicil Defteri. KKTC Millî Arşiv, No. 26. Kıbrıs Şer'îye Sicil Defteri. KKTC Millî Arşiv, No. 27. Kıbrıs Şer'îye Sicil Defteri. KKTC Millî Arşiv, No. 28. Kıbrıs Şer'îye Sicil Defteri. KKTC Millî Arşiv, No. 29. Kıbrıs Şer'îye Sicil Defteri. KKTC Millî Arşiv, No. 32. Kıbrıs Şer'îye Sicil Defteri. KKTC Millî Arşiv, No. 38. Kıbrıs Şer'îye Sicil Defteri. KKTC Millî Arşiv, No. 41. Kıbrıs Şer'îye Sicil Defteri. KKTC Millî Arşiv, No. 44. Kıbrıs Şer'îye Sicil Defteri. KKTC Millî Arşiv, No. 45. Kıbrıs Şer'îye Sicil Defteri. KKTC Millî Arşiv, No. 46.

VGMA, Vakıflar Genel Müdürlüğü Arşivi. Lala Mustafa Paşa Vakfiyesi. No. 746, sayfa 163, sıra 70. 